\title{
Türkiye'de Çıkan Endüstriyel Yan Ürünlerin Dolgu Özellikleri Üzerine Deneysel Bir İnceleme
}

\author{
Irem Zeynep YILDIRIM ${ }^{1}$
}

\section{ÖZ}

Çelik cürufu ve uçucu kül sırasıyla çelik üretim tesislerinde ve termik santrallerde katı partiküller halinde ortaya çıkan endüstriyel yan ürünlerdir. $\mathrm{Bu}$ çalışmada dolgu uygulamalarında kullanılabilmeleri için, uçucu kül ve ağırlıkça \%20 uçucu kül içeren çelik cürufu-uçucu kül karışımının özellikleri incelenmiştir. Uçucu kül ve çelik cürufu, özgül ağırlık, elek, hidrometre ve Atterberg limitleri deneyleriyle karakterize edilmiştir. Kompaksiyon davranışı standart Proktor deneyleriyle belirlenen yan ürünlerin ve karışımın hidrolik iletkenlik katsayıları düşen seviyeli permeabilite deneyleriyle belirlenmiştir. Yan ürünlerin ve karışımın kayma dayanımı parametreleri \%100 Standart Proktor sıkılığında hazırlanan numuneler üzerinde yapılan kesme kutusu deneylerinin sonuçlarına göre değerlendirilmiştir. $\mathrm{pH}$ ve elektrik iletkenliği ölçümleri ve sızıntı suyu analizleri yapılarak malzemelerin kullanımıyla oluşabilecek çevresel risklerin belirlenmesi hedeflenmiştir. Kompaksiyon deneylerinde $\% 80$ çelik cürufu- $\% 20$ uçucu kül karışımı için elde edilen kuru birim hacim ağırlığı çelik cürufuna göre daha yüksek, karışma ait optimum su muhtevası çelik cürufuna göre daha düşüktür. Kesme kutusu deney sonuçlarına göre, deney-sonu sürtünme açısı, çelik cürufu ve uçucu kül için sırasıyla $40.1^{\circ}$ ve $28.9^{\circ}$ 'dir. $\% 80$ çelik cürufu\%20 uçucu kül karışımının deney-sonu sürtünme açısı ise $37.8^{\circ}$ 'dir. Karışımın pik kayma dayanımı çelik cürufu için elde edilene yakın ve dolgu için kullanılan doğal kum malzemeleri için elde edilen değerlerin üst sınırı ile karşılaştırılabilir. pH ve elektrik iletkenliği ölçümleri, kullanılan yan ürünlerin korozif özellikler gösterebileceğine işaret etmektedir. Çelik cürufu ve uçucu kül numuneleri için yapılan sızma suyu analiz sonuçları çevre etkilerinin üretilen karışım için araştırılması gerektiğine işaret etmektedir.

Anahtar Kelimeler: BOF çelik cürufu, uçucu kül, kompaksiyon, permeabilite, kayma dayanımı, çevresel riskler.

\footnotetext{
Not: Bu yazı

- Yayın Kurulu'na 27 Aralık 2020 günü ulaşmıștır. 20 Eylül 2021 günü yayımlanmak üzere kabul edilmiştir.

- 31 Ocak 2023 gününe kadar tartı̧̧maya açıktır.

- https://doi.org/10.18400/tekderg.847828
}

1 Boğaziçi Üniversitesi, İnşaat Mühendisliği Bölümü, İstanbul zyildirim@boun.edu.tr - https://orcid.org/0000-0003-1820-2607 


\section{ABSTRACT \\ An Experimental Investigation on the Fill Properties of Industrial By-Products Generated in Turkey}

Steel slag and fly ash are particulate industrial by-products generated in steel plants and power plants, respectively. In this study, the properties of steel slag, fly ash and a steel slagfly ash mixture that contain $20 \%$ fly ash (by weight) were investigated for their possible use as fill material. Fly ash and steel slag were characterized through specific gravity, sieve, hydrometer and Atterberg limits experiments. Compaction behavior of the industrial byproducts and their mixture were evaluated through standard Proctor compaction, and their hydraulic conductivity were determined through falling-head permeability experiments. The shear strength parameters of the industrial by-products and their mixtures, prepared at $100 \%$ Proctor compaction, were evaluated based on direct shear experiments. $\mathrm{pH}$ and electrical resistivity measurements were taken, and leachate analysis were performed on fly ash and steel slag samples to determine the possible environmental risks that can arise from their use. The maximum dry unit weight values recorded for the $80 \%$ steel slag - $20 \%$ fly ash mixture was higher, on the other hand, the optimum moisture content of the mixture was lower compared to that of steel slag sample. Based on direct shear experiments, the end-of-test friction angles are $40.1^{\circ}$ and $28.9^{\circ}$ for steel slag and fly ash, respectively. The end-of-test friction angle for the $80 \%$ steel slag- $20 \%$ fly ash mixture is $37.8^{\circ}$. The peak shear strength of the mixture is close to that of steel slag and comparable to the higher end of the range obtained for natural sands that are used as fill material. The $\mathrm{pH}$ and electrical resistivity measurements indicate that these by-products may possess corrosive nature. The results of the leachate analysis point toward the need for further analysis of the mixture for the environmental effects.

Keywords: BOF steel slag, fly ash, compaction, permeability, shear strength, environmental risks.

\section{GİRIŞ}

Tüm dünyada olduğu gibi ülkemizde de nüfus artışı ve beraberinde gelen endüstrileşmenin bir sonucu olarak atık sorunu büyümekte, çevreye duyarlı ve sürdürülebilir bir sistem kurmak her geçen gün daha da önem kazanmaktadır. Gelişmiş ülkelerde çeşitli malzemelerin faydalı kullanım oranları Türkiye'ye kıyasla çok daha yüksektir. Bu oranın ülkemizde yükselmesi ancak endüstrinin ihtiyaçlarını karşılayan akademik çalışmalarla yerel malzemelerin daha iyi anlaşılması ve uygulama projelerinde kullanılması sonucu mühendislerin deneyim kazanmasıyla mümkün olabilir. Bu açıdan bakıldığında akademi ile endüstri arasında birbirini besleyen bütünleşik bir yapı kurulmasının önemi ortaya çıkmaktadır. Son yıllarda Avrupa Birliği'nin ve ülkemizin desteği ile geri dönüşüm konusu ile ilgili başlatılan çağrılı araştırma programları ve desteklenen araştırma projeleri umut vericidir.

Hızlı sanayileşme tüm endüstriyel yan ürünlerin faydalı kullanılması ihtiyacını doğurmuştur. Sıfır atık hedefinin gerçekleşmesi ancak yerel yan ürünlerin doğru karakterize edilmesi ile mümkündür. $\mathrm{Bu}$ aşamada bazen birden fazla yan ürünü birlikte kullanarak istenen mühendislik özelliklerine sahip karışımlar elde etmek daha uygun bir kullanım stratejisi olabilir. Türkiye'deki yüksek üretim rakamları nedeniyle, endüstriyel yan ürünler arasından 
çelik cürufu ve uçucu kül, faydalı kullanılması gereken malzemeler arasında öne çıkmaktadır. Çelik cürufu, metal üretim tesislerinde, uçucu kül de termik santrallerde ortaya çıkan parçacıklardan oluşan yan ürünlerdir. Bu yan ürünlerin faydalı kullanılamayan fazlası, önce yığınlar halinde bekletilmekte, atık olarak kontrollü olarak düzenli depolama sahalarında gömülmekte ya da hiç tercih edilmeyen bir yöntemle çeşitli alanlarda kontrolsüz gömülmektedir. Bu vahşi depolama yöntemi nedeniyle oluşabilecek çevre problemlerimin ortadan kalkması ve doğal kaynaklarımız arasında olan zeminlerin ve kayaçların korunması için bu yan ürünlere inşaat malzemesi olarak değer kazandırmak ülkemizde önemli bir ihtiyaç haline gelmiştir [1-3].

Çelik cürufunun kullanılmasıyla ilgili çalışmaların çoğunluğu, çelik cürufunun asfalt agregası [4-7], beton agregası [8-12], çimento katk1 malzemesi [14-19], ve klinker malzemesi [19-21] olarak değerlendirilmesine yöneliktir. Çelik cürufunun geoteknik özellikleri ile ilgili çalışmalar ise son beş yıl içinde hız kazanmıştır. Çelik cürufunun en temel iki geoteknik uygulama şekli: (i) zemin stabilizasyon malzemesi [22-24], ve (ii) yol dolgu malzemesi [25-27] olarak kullanılmasıdır. Temel amacın çok miktarda çelik cürufunun faydalı kullanılması olduğu düşünülürse, yol dolgu malzemesi uygulamaları yüksek hacimlerde çelik cürufunun değerlendirilmesi açısından stabilizasyon uygulamalarına kıyasla oldukça avantajlıdır. Çelik cürufunda bulunan kireç $(\mathrm{CaO})$ ve periklas $(\mathrm{MgO})$, suya erişimleri sağlandığında, şişmeye ve hacimsel dengesizliğe sebep olabilecek şekilde hidratasyon geçirirler. Özellikle bu bileşenlerin çelik cürufunda serbest halde bulunması durumunda, su varlığında şişme miktarları da göz ardı edilmesi zor düzeylere ulaşabilmekte bu da kullanımını kisitlamaktadır [28-30].

Faydalı kullanım öncesinde seçilen yan ürünlerin kimyasal yapılarının, sızma suyuna metal salım özelliklerinin incelenmesi ve çevresel risklerin belirlenmesi gerekmektedir. Belirlenen riskler için uzun-süreli çevresel etkilerin değerlendirilmesi ve potansiyel olumsuz etkileri azaltacak stratejiler belirlenmesi gerekir. Ancak uzun-süreli çevresel etkilerin de değerlendirildiği bütünsel bir yaklaşımla bu yan ürünlerin faydalı kullanılması mümkün olabilir.

\section{TÜRKIYE'DE ÇELIKK CÜRUFU VE UÇUCU KÜL ÜRETIMI}

Yan ürünlerin faydalı kullanılması; üretim aşamasından itibaren doğru sınıflandırılmaları, işleme aşamalarının ve depolamanın takibi, depodan çıkan yan ürünlerin satış, bertaraf ve faydalı kullanım miktarlarının belirlenmesi ve son olarak kullanıldıkları uygulamaların sürekli takibi ile mümkün olabilir. Birçok ülkede olduğu gibi Türkiye'de de yan ürün takibinin getirdiği ek maliyetler ve geçmişten süregelen kontrolsüz yüksek bertaraf rakamları, özellikle de küçük işletmelerde yan ürün kontrol kültürünün gelişmesini yavaşlatmaktadır.

\section{1. Çelik Cürufu}

Çelik cürufu üretim metoduna bağlı olarak bazik oksijen ocağı (BOF) çelik cürufu, elektrik ark ocağ 1 (EAF) çelik cürufu ve pota ocağ 1 (LF) çelik cürufu olmak üzere üç ana kategoride sınıflandırılır [29]. 2017 senesindeki verilere göre, 37.5 milyon ton'luk (Mt'luk) çelik üretimiyle, çelik üreten ülkeler arasında Türkiye Dünya'da 8. sırada ve Avrupa'da da 2. 
sırada yer almıştır. Çelik ihraç eden ülkeler arasında ise $15 \mathrm{Mt}$ 'lik çelik ihracatıyla 10. sırada yer almıştır [31]. Ekonomik dalgalanmalar nedeniyle 2019 yılının ilk sekiz (8) aylık döneminde yıllık ham çelik üretimi \%10 düşse de Türkiye 2018 yılı verilerine göre ham çelik üretimi miktarları sıralamasında ilk on (10) ülke arasındadır [32,33].

Türkiye Çelik Üreticileri Derneği (TÇÜD) tarafından yayımlanan bilgilere göre Türkiye'de yaklaşık 30 tane çelik üretim tesisi faaliyet göstermekte ve bu tesisler Marmara, Karadeniz, İzmir ve İskenderun olmak üzere dört bölgede yoğunlaşmaktadır. Bu tesislerden sadece üç (3) tanesi bütünleşmiş demir çelik (BOF) tesisiyken, geri kalan 24 tanesi elektrik ark ocaklı (EAF) ve üç (3) tanesi de indüksiyon ocaklıdır. EAF tipi üretim tesislerinin sayısı BOF tipi üretim tesislerinden daha yüksek olsa da, EAF tipi ocakların görece düşük üretim kapasitesi nedeniyle Türkiye'de üretilen çelik miktarının yaklaşık 1/3'ü bütünleşmiş demir-çelik tesislerden gelmektedir [34,35]. Çelik üretimi sırasında üretim operasyonun verimliliğine ve girilen malzeme özelliklerine göre, genellikle çelik üretiminin yaklaşık \%10-20'si kadar çelik cürufu da yan ürün olarak çıkmaktadır.

Türkiye'de son yıllarda çelik cürufu kullanımı ile ilgili Karayolları Genel Müdürlüğü (KGM)'nün ve yerel çelik üreticilerinin de desteğiyle sürdürülen ARGE çalışmalarının sonuçlarına göre, cüruf deneme yollarında kullanılmış ve deneme yollarındaki performans ölçüm sonuçlarına dayalı olarak çelik cürufunun agrega olarak kullanımına ilişkin bir mevzuat önerisi hazırlanmıştır. Tüm çabalara rağmen çelik cürufunun kullanımı ülkemizde henüz istenilen düzeyde değildir. TÇÜD’nin raporunda çeşitli illerde çelik cürufu çıktısı ve geri kazanılan miktarlar yayımlamıştır. Yayımlanan raporlardan elde edilen veriler, Türkiye'de üretilen çelik cürufunun yaklaşık olarak \%60'ının faydalı kullanılamadığına ve atık kategorisinde bertaraf edildiğine işaret etmektedir [33].

Öcal (2018), Türkiye'deki demir çelik sektörüne ait tüm atıkları ve atık yönetimini değerlendirdiği uzmanlık tezinde, yarısından fazlası faydalı kullanılamayan çelik cürufunun değer kazanmasının önemini ve bu konuda yapılacak çalışmaların gerekliliğini vurgulamıştır [36].

\subsection{Uçucu Kül}

Termik santrallerde ortaya çıkan en önemli yan ürün olan uçucu kül, baca gazlarıyla çıkan ve filtreler yardımıyla toplanan katı kül tanecikleridir. Ülkemizdeki toplam elektrik üretiminin yaklaşık \%37'sine karşılık gelen önemli bir pay, kömürle çalışan çok sayıda termik santrale aittir [37].

Uçucu küller Amerikan Malzeme Test Standartları (ASTM) C 618'deki kimyasal bileşen sınırlamalarına göre F sınıfı ve C sınıfı olmak üzere iki temel sınıfa ayrılmaktadır. Her iki sınıflandırma için de uçucu külün kimyasal bileşiminde $\mathrm{SiO}_{2}$ (Silika), $\mathrm{Al}_{2} \mathrm{O}_{3}$ (Alümina), ve $\mathrm{Fe}_{2} \mathrm{O}_{3}$ (Demir oksit) bileşenlerinin toplamının \%50'nin üzerinde olması gerekirken, yenilenen ASTM standardına göre bir uçucu külün $\mathrm{C}$ sınıfı olabilmesi için $\mathrm{CaO}$ bileşeninin $\% 18$ 'in üzerinde olması gerekir. Bu nedenle, $\mathrm{C}$ sınıfı uçucu küller puzzolan özelliklerinin yanı sıra genellikle su varlığında kendiliğinden bağlayıcı özelliğe de sahiptir [38]. C sınıfı küller çimento katkı maddesi olarak ve zemin stabilizasyonunda F sınıfı küllere kıyasla daha yaygın kullanılmaktadır. Türkiye'deki termik santrallerde çoğunlukla linyit, buna ek olarak taş kömürü ve ithal kömür de yakıt olarak kullanılmaktadır. Başlıca termik santrallerden elde 
edilen uçucu kül örneklerinin kimyasal analiz sonuçları bu santrallerin yaklaşık yarısında $\mathrm{C}$ tipi ve kalanında F tipi uçucu kül üretildiğine işaret etmektedir [39,40]. Ancak bu analiz ve değerlendirmelerin çoğu, ASTM C 618'in 2019 revizyonundan önceki (C sınıfı kül için minimum \% $19 \mathrm{CaO}$ bileşeni şartı olmayan) versiyonu ile yapıldığ 1 için daha önce $\mathrm{C}$ sınıflandırılması yapılan birçok uçucu kül sınıflandırmasının yeni standarda göre değişeceği öngörülebilir.

2016 verilerine göre, Türkiye'deki kurulu gücü 100 megawatt (MW) ve üzeri olan tüm faal termik santrallerde yaklaşık olarak 19.5 Mt toplam atık ortaya çıkmıştır. $\mathrm{Bu}$ 19,5 Mt \%87.8'ini kül ve diğer katı atıklar oluşturmaktadır. Bu atık miktarının sadece 12 bin tonu tehlikeli atık, geri kalanı tehlikeli olmayan katı atık kategorisinde olmasına rağmen, atığın büyük bir kısmı: \%83.3’ü kül dağı ve kül barajı olarak kaydedilmiş veya düzenli depolama tesislerinde bertaraf edilmiştir. Verilere göre uçucu kül üretiminin \%16.7'si ise atık geri kazanım tesislerine ve kullanım için maden/taş ocaklarına gönderilmiştir [41]. 2020 yılına ait uçucu kül çıktısının 25 Mt civarında olacağı tahmin edilmektedir. Uçucu külün faydalı kullanılması ülkemiz açısından ekonomik ve çevresel bir ihtiyaçtır [42].

\section{3. ÇALIŞMANIN MOTIVASYONU VE KARIŞIMIN BELIRLENMESI}

Ülkemizde ve tüm dünyada sıfır atık hedefine ulaşılması tüm çelik cürufu çeşitlerinin faydalı kullanılabilmesi ile mümkün olabilir. Son yıllarda sürdürülen araştırmaların çoğu EAF çelik cürufunun kullanılmasına yoğunlaşsa da BOF çelik cürufu çıktısı ülkemizdeki toplam çelik cürufu çıktısının hala önemli bir bölümünü oluşturmaktadır [34]. BOF çelik cürufunun geri kazanımıyla ilgili yapılan uluslararası çalışmalar arasında malzemenin demiryolu balastı olarak kullanılması ve açık gradasyonlu agrega olarak asfalt karışımlarında kullanımı da vardır $[43,44]$. BOF çelik cürufunun faydalı kullanımını kısıtlayan en önemli özelliği su varlığında hacimsel genleşme olduğu için yürütülen araştırmaların çoğu malzemenin genellikle çakıl boyutundaki kısmının kullanılmasına yöneliktir ve kum boyutundaki malzemenin dolgu olarak kullanılması ile ilgili yapılan çalışmalar oldukça sınırlıdır [30]. Bunun sebepleri malzemenin özelliklerinin anlaşılmaması ve şişme potansiyeli, kirletici salımı ve alkalinite gibi çevresel etkilerin nasıl azaltılacağının tam olarak bilinmemesidir.

$\mathrm{Bu}$ konudaki önemli çalışmalardan biri Dayıoğlu (2016) tarafından yapılmıştır. Dayıoğlu'nun elde ettiği sonuçlar ince danelerden oluşan alimuna bazlı su arıtma kalıntısı ile kaplanan (işlem gören) BOF tipi çelik cürufunun şişme miktarlarının, malzemenin temel ve alt temel yol dolgu malzemesi olarak kullanılabilecek düzeylere indiğini gösterirken, malzemenin $\mathrm{pH}$ yükselten özelliğinin çalışılması gerekliliğine de işaret etmektedir [45]. Dayığlu ve diğ. (2018) yaptıkları deneysel çalışma sonucunda alumina kaynağı yüksek bir atık malzemesi kullanılarak BOF tipi çelik cürufunun alkalinitesinin azaltılabileceğini ve yaptıkları model çalışması sonucunda da sızıntı suyu tampon görevi gören bir dolgu zemininden geçtikten sonra sızıntı suyuna salınan metal değerlerinin, EPA içme suyu limitlerinin altına düştüğünü göstermiştir [46].

Çelik cürufunun şişmesini azaltmak için kullanılabilecek bir başka yöntem de, çelik cürufunu başka malzemelerle karıştırarak yeni geo-malzemeler üretmektir [47,48]. Literatürdeki çalışmalarda çelik cürufu karışımlarında kullanılabilecek malzemeler içinde uçucu kül öne çıkmaktadır [49-50]. Yildirim ve Prezzi (2015), uzun süreli şişme deney sonuçlarına dayanarak sıkıştırılmış BOF çelik cürufu - \%10 uçucu kül karışımı örneklerine ait genleşme 
yüzdelerinin sıkıştırılmış sade çelik cürufu ile kıyaslandığında çok daha düşük seviyelerde olduğunu göstermiştir [30].

Türkiye'de çok miktarda çıkan ve faydalı kullanılamayan BOF çelik cürufunun faydalı kullanılabilmesi için öncelikle su varlığında hacimsel genleşme miktarının mühendislik açısından önemsiz seviyelerde kalmasını sağlayacak karışımlar üretilmesi hedeflenmiştir. Bu konuda 2017'den beri sürdürülen araştırma projesinin ilk aşamasında ASTM D1883'e uygun olarak serbest şişme deneyleri yapılmıştır [51,52]. \%100 Standart Proktor sıkılığında hazırlanan çelik cürufu (ÇÇ) ve \%80 çelik cürufu - \%20 uçucu kül karışımı (ÇÇ80UK20) için elde edilen uzun süreli serbest şişme sonuçları Tablo 1'de özetlenmektedir.

Tablo 1 - Uzun-süreli serbest şişme deneylerinde ölçülen hacimsel deformasyonlar

\begin{tabular}{ccccccc}
\hline \multicolumn{7}{c}{ Hacimsel Deformasyonlar (\%) } \\
\hline Deney Süresi & 30.gün & 60.gün & 90.gün & 120.gün & 150.gün & 180.gün \\
\hline \hline ÇÇ & 1.009 & 1.803 & 2.308 & 2.912 & 3.379 & 3.605 \\
ÇC80UK20 & 0.122 & 0.500 & 0.690 & 0.701 & 0.727 & 0.734 \\
\hline
\end{tabular}

Notlar:

(1) Çelik cürufu (2) \%80 çelik cürufu - \%20 uçucu kül karışımı

Tablo 1 verilerine göre, çelik cürufunun - ağırlıkça \%20'si kadar - uçucu kül ile yer değiştirilerek hazırlanan karışımın düşey deformasyonu altı (6) ayın sonunda (\%1'nin altında) mühendislik açısından kabul edilebilir seviyelerdedir. Karışımların hacimsel genleşme değerlerinin kabul edilebilir düzeye inmesi, üretilen karışımların kullanılabilmesi için yeterli değildir. Karışımların dolgu malzemesi olarak kullanılabilirliğinin belirlenmesi için öncelikle malzemeye ait tüm geomekanik özelliklerin ve çevresel risklerin laboratuvar çalışmalarıyla belirlenmesi gerekir. Uzun-süreli çevresel etkilerin de model, saha ve laboratuvar çalışmalarıyla değerlendirilmesi gerekir. Bu çalışmanın odağı, çelik cürufu, uçucu kül ve \%80 çelik cürufu - \%20 uçucu kül karışımının dolgu uygulamaları için geomekanik özelliklerini karşılaştırarak irdelemek ve çelik cürufu ve uçucu kül kullanımıyla oluşabilecek çevresel riskleri belirlemektir. Uzun-süreli çevresel etkileri değerlendirmek bu çalışmanın kapsamı dışındadır.

\section{KULLANILAN YAN ÜRÜNLER}

Bu çalışmada iki yan ürün: (i) BOF ile üretim yapan bütünleşmiş bir demir çelik tesisinden elde edilen çelik cürufu ve (ii) Trakya Bölgesi'nde faaliyet gösteren bir termik santralden elde edilen uçucu kül kullanılmıştır. Projenin başlangıç aşamasında varillerle laboratuvara yollanan çelik cürufundan bütünü temsil eden dane çapı dağılımına sahip örnekler elde edebilmek için ASTM C 702'ye uygun olarak, dört (4) parçaya bölme tekniği uygulanmıştır. Bütünü temsil eden dane çapı dağılımına sahip yan ürün örnekleri Şekil 1a ve 1 b'de görülmektedir [53]. Kullanılan çelik cürufu ve uçucu külün kimyasal bileşimi Tablo 2'de görülmektedir. ASTM C618’e göre, kullanılan uçucu kül F sınıfıdır. 

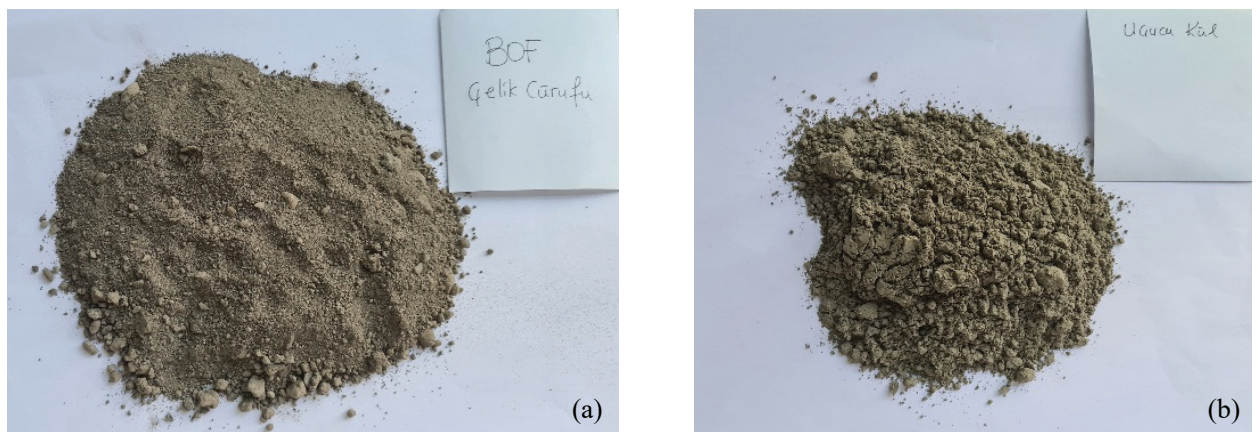

Şekil 1 - Kullanılan yan ürünler: (a) Çelik cürufu (ÇÇ), (b) Uçucu kül (UK)

Tablo 2 - Yan ürünlerin kimyasal bileşenleri

\begin{tabular}{ccc}
\hline Bileşenler & $\mathrm{ÇÇ}^{(1)}$ & $\mathrm{UK}^{(2)}$ \\
\hline \hline $\mathrm{SiO}_{2}(\%)$ & 9.92 & 63.18 \\
$\mathrm{Al}_{2} \mathrm{O}_{3}(\%)$ & 2.14 & 18.69 \\
$\mathrm{Fe}_{2} \mathrm{O}_{3}(\%)$ & 24.84 & 8.53 \\
$\mathrm{CaO}(\%)$ & 55.2 & 3.27 \\
$\mathrm{MgO}(\%)$ & 1.52 & 2.65 \\
$\mathrm{SO}(\%)$ & 0.64 & 0.18 \\
$\mathrm{MnO}(\%)$ & 2.15 & - \\
$\mathrm{P}_{2} \mathrm{O}_{5}(\%)$ & 1.46 & - \\
$\mathrm{V}_{2} \mathrm{O}_{5}(\%)$ & 1.07 & - \\
$\mathrm{Na}_{2} \mathrm{O}(\%)$ & - & 1.46 \\
$\mathrm{~K}_{2} \mathrm{O}(\%)$ & - & 1.67 \\
\hline
\end{tabular}

Notlar: ${ }^{(1)}$ Çelik cürufu ${ }^{(2)}$ Uçucu kül

Deneylerde kullanılan çelik cürufu örneklerinin özdeş dane dağılımlarına sahip olmasını sağlamak için, bütünü temsil eden dane çapı dağılımı belirlenmiş ve malzeme çeşitli elek aralıklarında kalan danelere $(0-0.425 \mathrm{~mm}, 0.425-0.85 \mathrm{~mm}, 0.85-2 \mathrm{~mm}, 2-4.75 \mathrm{~mm}, 4.75-$ $9.5 \mathrm{~mm}$ ) ayrılmıştır. Standart dane çapı dağılımı için belirlenen ağırlık yüzdelerine karşılık gelen dane aralıklarından malzemeler karıştırılarak özdeş örnekler hazırlanmıştır.

Bu çalışmada (i) BOF çelik cürufu (ÇC), (ii) Uçucu kül (UK) ve (iii) BOF çelik cürufu- uçucu kül karışımı (ÇC80UK20) incelenmiştir. Karışım ağırlıkça \%80 çelik cürufu, \%20 uçucu kül içerecek şekilde hazırlanmıştır. 


\section{DENEY YÖNTEMLERI}

BOF çelik cürufu ve uçucu kül örneklerinin dane çapı dağılımları elek ve sedimentasyon analizleri yapılarak ASTM D422-63'e, özgül ağırlıkları ise ASTM D854-10'a uygun olarak belirlenmiştir $[54,55]$. Çelik cürufu ve çelik cürufu-uçucu kül karışımı $150 \mathrm{~mm}$ çapında ve uçucu kül ise $100 \mathrm{~mm}$ çapında kalıplarda Standart Proktor enerjisiyle sıkıştırılarak, malzemelerin su muhtevası-kuru birim ağırlık $\left(w-\gamma_{\mathrm{d}}\right)$ ilişkileri ASTM D698-00'a uygun şekilde belirlenmiştir [56]. Geçirimlilik deneyleri için, kaba daneli zeminlerin de Standart Proktor sıkılığında hazırlanabilmesini sağlayan $150 \mathrm{~mm}$ çapında $116 \mathrm{~mm}$ yüksekliğinde ve su çıkışı ölçümünü kolaylaştıran bir çıkış ağızlığına sahip özel yapım bir kalıp kullanılmıştır (bkz. Şekil 2a). Proktor sıkılığında hazırlanan örneklerden dane çapı dağılımlarına bağlı olarak en az 72 ile 168 saat süreyle su geçirilerek doygun olmaları sağlandıktan sonra, düşen seviyeli permeabilite deney metodu kullanılarak hidrolik iletkenlik katsayıları belirlenmiştir. [57]. \%100 Proktor sıkılığında örnekler hazırlamak için gerekli malzeme miktarı kesme deneyinde kullanılan kutu hacmine göre belirlendikten sonra, optimum su muhtevasında $\left(w_{\text {opt }}\right)$ hazırlanan uçucu kül, çelik cürufu, ve karışım kutu içinde tabakalar halinde sıkıştırılmıştır. Sıkıştırılma işılemi bir tokmak yardımıyla yapılırken, homojenliği sağlamak için her tabaka için yükseklik ölçümleri yapılmıştır (bkz. Şekil 2b).

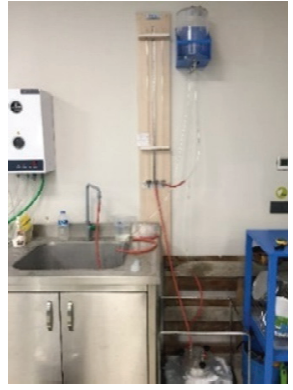

(a)

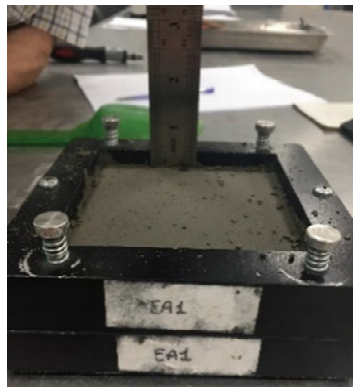

(b)

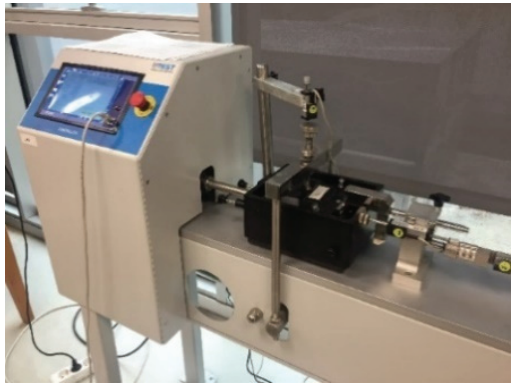

(c)

Şekil 2 - Permebilite ve kayma dayanımı deneyleri: (a) Hidrolik iletkenlik, (b) Direk kesme kutusunda numune hazırlanmasl, (c) Direk kesme deney cihazı

Tüm örnekler $100 \times 100 \times 30$ mm'lik kare kutuda hazırlanmıştır. Deney sırasında düşey ve yatay deplasmanlar sirasiyla $\pm 10 \mathrm{~mm} \times 0.001 \mathrm{~mm}$ 'lik ve $\pm 25 \mathrm{~mm} / 0.001 \mathrm{~mm}$ 'lik potansiyometrik deplasman sensörleri (LVDT) kullanılarak, yük ise $5 \mathrm{kN}$ 'luk bir yük hücresiyle ölçülmüştür (bkz. Şekil 2c). Hazırlanan örnekler hedeflenen normal gerilmeler altında $0.125 \mathrm{~mm} /$ dakika hızında kesilmiştir [58]. Deney sonunda yan ürünlerin kalıcı (kritik-durum) içsel sürtünme açılarına yaklaşabilmek için, kesme kutusu deney aletinin fiziksel limitleri içindeki maksimum yatay deplasman seviyesine (22-23 mm'ye) ulaşmak için sistemde modifikasyonlar yapılmıştır.

$\mathrm{Bu}$ yan ürünlerin kullanılmasının çevresel risk taşıyıp taşımadığının belirlenebilmesi için pH ve elektrik iletkenliği ölçümleri yapılmıştır. Elektrik rezistansı ASTM G187 - 18'e uygun olarak iki pimli yöntem kullanılarak ölçülmüştür [59]. Bu ölçümü yapabilmek için iki başında iletken elektrotlar olan $60 \times 60 \times 12$ mm'lik pleksiglass bir kutu üretilmiştir. Tüm örnekler Şekil 3a'da görüldüğü gibi \%100 Proktor sıkılığında ve optimum su muhtevasında bu 
elektrotlu kutuda sıkıştırılarak hazırlanmıştır. Hazırlanan numunelerin elektrik iletkenliği, iki iletken elektrot arasında farklı frekanslarda akım uygulayabilen ve aradaki voltaj farkını belirleyebilen bir cihaz ile ölçülmüştür (bkz. Şekil 3b). Hazırlanan numuneler en az 18 saat suya doyurularak bekletildikten sonra elektrik iletkenliği ölçümleri tekrarlanmıştır. pH ölçümleri sıkıştırılan ve suya doyurulan numuneler içine minimum üç noktada, Şekil 4a'da görüldüğü gibi elektronik $\mathrm{pH}$ probu daldırılarak alınmıştır. Çelik cürufu, uçucu kül ve \%80 çelik cürufu - \%20 uçucu kül karışımı için $10 \mathrm{~g}$ malzeme $/ 100 \mathrm{~mL}$ arıtılmış su oranı kullanılarak ikişer eluat hazırlanmıştır. Hazırlanan eluat örnekler cam kavanozlar içinde Şekil 4b'de görüldüğü gibi 24 saat çalkalandıktan sonra Şekil 4c'deki gibi pH probu kavanoza daldırılarak ölçümler tekrarlanmıştır [60].

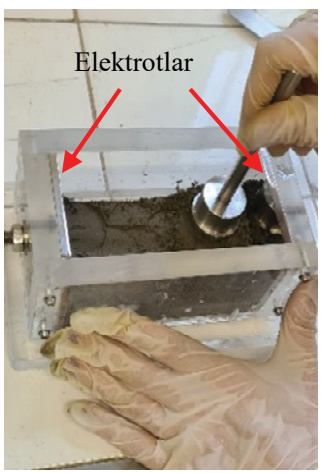

(a)

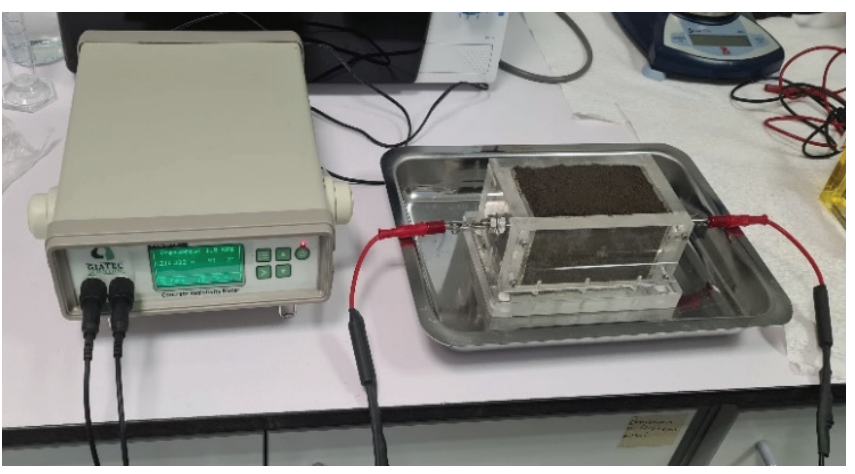

(b)

Şekil 3 - Elektrik iletkenliği deneyi: (a) Numune hazırlanışı, (b) Elektrik rezistansı ölçümü

Olası ağır metal salımlarını belirlemek için sızıntı suyu analizleri yapılmıştır. Çelik cürufu ve uçucu kül numunesi eluatı TS EN 12457-4 [61] standardına uygun olarak analizler için hazırlanmıştır. Eluat analizleri, çeşitli ağır metal parametreleri için EPA 6020 B(ICP-MS) [62], TS EN ISO 17852[63], ve TS 9546 EN 12880 [64], yöntemleri kullanılarak tamamlanmıştır.

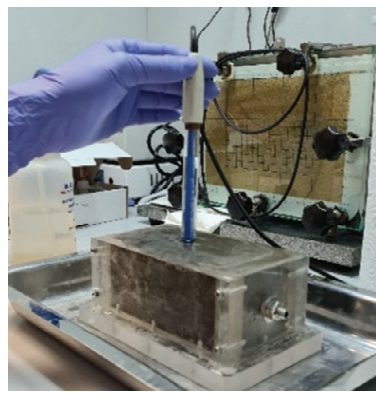

(a)

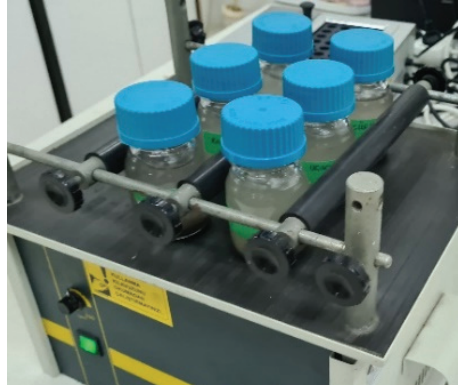

(b)

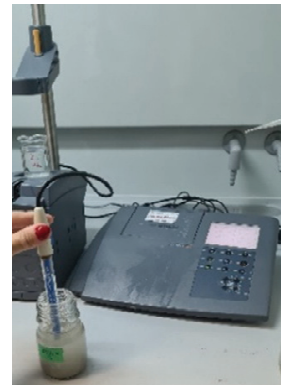

(c)

Şekil 4 - pH deneyleri: a) Sıkıştırılmış ve doyurulmuş örneklerde pH ölçümü, (b) Eluat hazırlanması, (c)Eluat örneklerde pH ölçümü 


\section{YAN ÜRÜNLERİN DOLGU ÖZELLİKLERİ}

\section{1. İndeks Özellikleri}

Çelik cürufu çelik üretim tesislerinde pit alanlarında sıcak/ergimiş halde dökülür ve soğuma sırasında değişik dane boyutlarına parçalanır. Daha sonra agrega tesislerindeki sistemlere benzer şekilde kırma ve boyutlandırma işlemlerinden geçirilir, metal ayrışması sonucunda işlenerek kalan kısım çelik cürufu olarak adlandırılır. Çelik cürufu içeriğindeki demir ve manganez içeriği nedeniyle ağırlıklı olarak silikat mineralleri içeren doğal kumlara göre daha ağırdır. Uçucu kül ise termik santral bacalarından uçarken toplanan, çok daha ince-genellikle silt boyutunda- hafif, uçucu danelerden oluşmaktadır. Uçucu kül, içeriğinde ağırlıklı olarak silikat mineralleri içermesi ve boşluklu yapısı nedeniyle genellikle silika kumlarından daha hafif yapıya sahiptir. Bu çalışmada kullanılan çelik cürufu ve uçucu kül örneklerinin özgül ağırlık değerleri Tablo 3'te verilmiştir.

Tablo 3 - Yan ürünlerin özgül ă̆ırlıkları

\begin{tabular}{cccc}
\hline Yan Ürün & ÇC $^{(1)}$ & UK $^{(2)}$ & ÇC80UK20(3) $^{(3)}$ \\
\hline \hline $\mathrm{G}_{\mathrm{s}}^{(4)}$ & 3.349 & 2.309 & 3.14 \\
\hline
\end{tabular}

Notlar:

(1) Çelik cürufu (2) Uçucu kül (3) \%80 çelik cürufu - \%20 uçucu kül karışımı ${ }^{(4)}$ Özgül ağırlık deneyleri ASTM D854-06'ya göre yapılmıştır.

Genellikle çelik üretiminin verimliliği yükseldikçe, çelik olarak alınamayan ve cüruf içinde kalan demir oksit miktarları da yükselmektedir. Bu çalışmada kullanılan çelik cürufunun özgül ağırlık değerleri bu ayrıştırılamayan demir oksit nedeniyle literatürde sunulanlardan biraz daha yüksektir [30]. Uçucu külün özgül ağırlığı ise benzer küller için belirlenen değerlere yakındır [40] ve doğal zeminlere göre daha hafiftir. Karışımın özgül ağırlığı ise yaklaşık olarak 3.14'tür.

Bu çalışmada kullanılan çelik cürufu, faydalı kullanımı görece daha zor olan 9.5 mm'lik elekten geçen danelerden oluşmaktadır. Şekil 5'te çelik cürufu, uçucu kül, \%80 çelik cürufu - \%20 uçucu kül karışımına ait dane çapı dağılımları sunulmuştur. Yan ürünlerin ve karışımın dane çapı dağılımı özellikleri Tablo 4'te özetlenmektedir.

Çelik cürufunun Amerikan Karayolları (AASHTO) sınıflandırması A-1b olduğu için, dane çapı dağılımı açısından, yol dolgu malzemesi olarak kullanılmaya uygun bir yan üründür. Buna kıyasla uçucu kül, ağırlıklı olarak silt boyutundadır, (AASHTO) ve ASTM standartları kullanılarak sırasıyla A-4 ve ML olarak sınıflandırılabilir. Çelik cürufunun ortalama dane çap1 (D $\mathrm{D}_{50}$ değeri) 0.86 mm iken, \%80 çelik cürufu - \%20 uçucu kül karışımı için bu değer 0.45 mm'dir. Çelik cürufu ve $\% 80$ çelik cürufu - \%20 uçucu kül içeren karışım ise Birleştirilmiş Zemin Sınıflandırma Sistemi'ne (USCS) göre sırasıyla SP-SM ve SM olarak sinıflandırılabilir. 


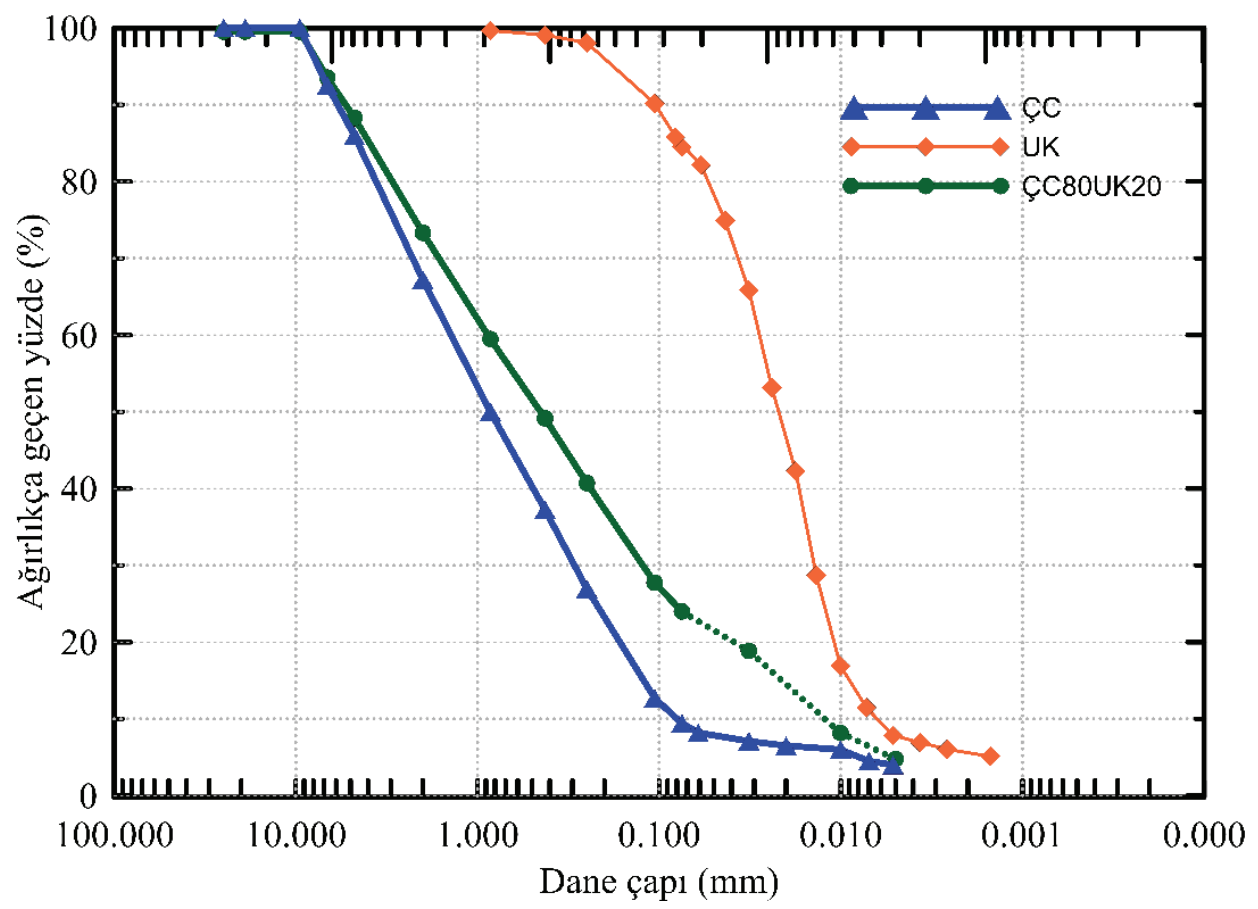

Şekil 5 - Çelik cürufu, uçucu kül, \%80 çelik cürufu -\%20 uçucu kül karışımının dane çapı dağllımlart

Tablo 4 - Dane çapı dağıllım özellikleri ve zemin sinıflandırması

\begin{tabular}{cccc}
\hline Yan Ürün & $\mathrm{CCC}^{(1)}$ & $\mathrm{UK}^{(2)}$ & ÇC80UK20 $^{(3)}$ \\
\hline \hline Atterberg Limitleri & $\mathrm{NP}^{(4)}$ & $\mathrm{NP}^{(4)}$ & $\mathrm{NP}^{(4)}$ \\
\hline$<$ No.10 (Geçen \%) & 67 & 100 & 73 \\
$<$ No.40 $($ Geçen $\%)$ & 37 & 99 & 49 \\
\hline $\mathrm{D}_{60}(\mathrm{~mm})$ & 1.4 & 0.028 & 0.86 \\
$\mathrm{D}_{50}(\mathrm{~mm})$ & 0.85 & 0.022 & 0.45 \\
$\mathrm{D}_{30}(\mathrm{~mm})$ & 0.3 & 0.013 & 0.12 \\
$\mathrm{D}_{10}(\mathrm{~mm})$ & 0.077 & 0.006 & $0.012^{(5)}$ \\
\hline Üniformluk Katsay1s1 $\left(\mathrm{C}_{\mathrm{u}}\right)$ & 18 & - & 72 \\
Derecelenme Katsayıs1 $\left(\mathrm{C}_{\mathrm{c}}\right)$ & 0.8 & - & 1.4 \\
\hline USCS & $\mathrm{SP}-\mathrm{SM}$ & $\mathrm{ML}$ & $\mathrm{SM}$ \\
AASHTO & $\mathrm{A}-1 \mathrm{~b}$ & $\mathrm{~A}-4$ & $\mathrm{~A}-1 \mathrm{~b}$ \\
\hline
\end{tabular}

Notlar:

(1) Çelik cürufu (2) Uçucu kül (3) \%80 çelik cürufu - \%20 uçucu kül karışımı ${ }^{(4)} \mathrm{NP}=$ Non-plastik

(5) Karışıma ait ortalama dane çapı dağılımından elde edilmiştir. 


\subsection{Kompaksiyon Davranışı}

Standart Proktor kompaksiyon deneyi sonuçlarına göre, çelik cürufu ve uçucu kül örneklerine ait su muhtevası - kuru birim hacim ağırlık ilişkileri $\left(w-\gamma_{d}\right)$ Şekil 6a'da görülmektedir. Şekil 6b'de ise çelik cürufu- uçucu kül karışımına ait Standart Proktor eğrisi, çelik cürufu için elde edilen eğriyle beraber sunulmaktadır. Şekil 6a'da görüldüğ̈̈ gibi çelik cürufunun $w-\gamma_{\mathrm{d}}$ ilişkisi, tamamıyla kuru ve tamamıyla doygun su muhtevalarında maksimum ağırlık değerlerine yaklaşan, iki pikli bir yapı göstermektedir. Çelik cürufunun kompaksiyon eğrisinde gözlenen bu iki pikli yapı çelik cürufu ile ilgili daha önce yapılan çalışmalarda elde edilen eğrilerle uyumludur [30]. Çelik cürufu gibi yan ürünlerin, kuru ya da kuruya çok yakın su muhtevasındaki kompaksiyonu sahada önemli derecede toz kalkışına sebep olarak çevresel sorunlar yaratmaktadır. Bununla beraber çok düşük su muhtevalarında sıkıştırılan zeminlerde su emmeye olan eğilim yükseldiği için, kuruya yakın değerler $w_{\text {opt }}$ seçimi için uygun değildir. Bunun tersi olan durum, ise malzemeden su çıkışının gözlendiği yüksek su muhtevası değerleridir. Laboratuvar deneyleri sırasında su muhtevasının \%17'nin üzerindeki değerlerinde çelik cürufu örneklerinden su çıkışı gözlenmiştir. $\mathrm{Bu}$ veriler değerlendirildiğinde çelik cürufuna ait kompaksiyon eğrisi için $w_{\text {opt }} \% 17$ olarak belirlenmiştir. Çelik cürufu oldukça yüksek $\gamma_{d}$ değerleriyle ağır bir dolgu malzemesidir.

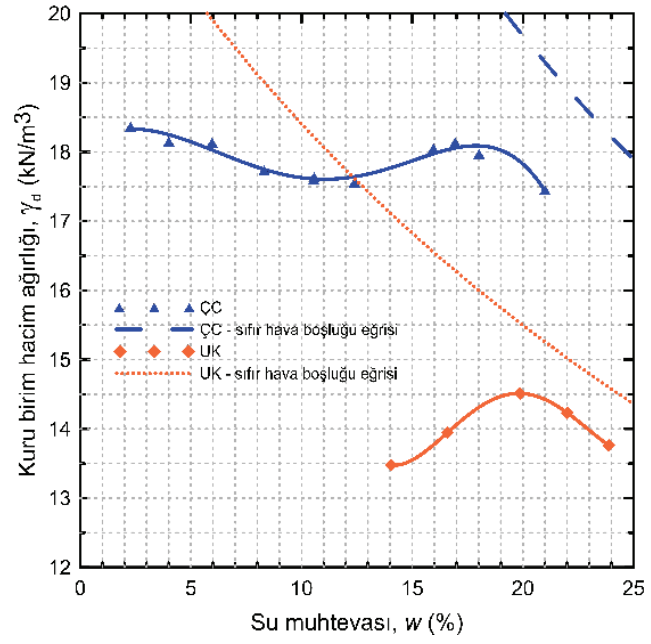

(a)

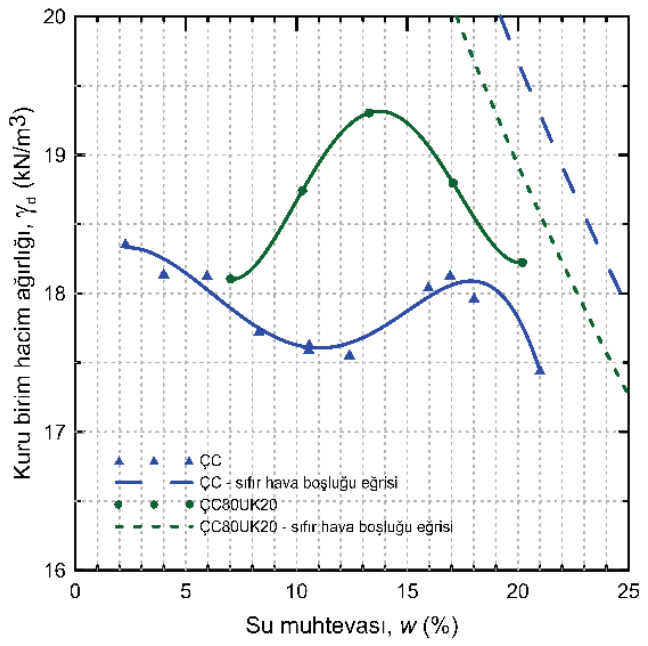

(b)

Şekil 6 - Kompaksiyon eğrileri:(a) ÇC ve UK (b) ÇÇ ve ÇC80UK20 karışıııı

Uçucu kül doğal zeminlere göre daha düşük bir özgül ağırlığa sahip olduğu için, Şekil 6a'da görüldüğü gibi uçucu külün $\gamma_{\mathrm{d}}$ değerleri, çelik cürufuna göre çok daha düşüktür. Ağırlıklı olarak silt boyutunda olan uçucu kül maksimum kuru birim hacim ağırlığına yaklaşık \%20 su muhtevasında ulaşmaktadır. Uçucu kül 13.5-14.5 kN/m³ aralığında değişen $\gamma_{\mathrm{d}}$ değerleri nedeniyle hafif bir dolgu malzemesi olarak değerlendirilebilir. Kompaksiyon deneylerinden elde edilen değerler Tablo 5'te özetlenmektedir. 
Şekil 6b'de görüldüğü gibi uçucu kül daha hafif bir dolgu malzemesi olsa da \%80 çelik cürufu - \% 20 uçucu kül karışımı deney yapılan su muhtevası aralığında çelik cürufundan daha yüksek kuru birim hacim ağırlıklara ulaşmaktadır. Bunun sebebi sıkıştırılma esnasında uçucu kül danelerinin çelik cürufu içindeki boşlukları doldurması ve karışımda daha kompakt/dolu bir dane-boşluk matrisi oluşmasıdır. İnce danenin artmasıyla beraber, karışımın $w_{\text {opt }}$ değeri ise \%3 düşmüştür. Karışımın kompaksiyon eğrisi incelendiğinde, uçucu külle yer değiştirme etkisiyle beraber çelik cürufuna ait eğrinin sola ve yukarı ötelendiği görülmektedir.

Tablo 5 - Standart Proktor kompaksiyon deneyi sonuçları

\begin{tabular}{cccc}
\hline Yan Ürün & ÇC $^{(1)}$ & $\mathrm{UK}^{(2)}$ & ÇC80UK20(3) $^{(3)}$ \\
\hline$\gamma_{\mathrm{d}, \max \left(\mathrm{kN} / \mathrm{m}^{3}\right)}{ }^{(4)}$ & 18.1 & 14.5 & 19.3 \\
\hline$w_{\text {opt }(\%)}{ }^{(4)}$ & 17 & 20 & 14 \\
\hline
\end{tabular}

Notlar:

(1) Çelik cürufu ${ }^{(2)}$ Uçucu kül (3) \%80 çelik cürufu - \%20 uçucu kül karışımı ${ }^{(4)}$ wopt $=$ optimum su muhtevası, $\gamma_{\mathrm{d} \max }=$ maximum kuru birim hacim ağırlığ ${ }^{(4)}$ Standart Proktor kompaksiyon deneyleri ASTM D698-00a'ya uygun olarak yapılmıştır.

\subsection{Hidrolik İletkenlik}

Doğal kum ve kum gibi özellik gösteren malzemelerin su geçirimliliği, dane çapı dağılımı özelliklerinin yanı sıra numunenin sıkıştırılma miktarına ve danelerin şekil özelliklerine de bağlı olarak geniş bir aralık göstermektedir. Tablo 6'da yan ürünler ve karışım için laboratuvarda elde edilen hidrolik iletkenlik katsayıları özetlenmektedir.

Tablo 6 - Yan ürünlerin laboratuvar permeabilite deneylerine göre hidrolik iletkenlik katsayılarl

\begin{tabular}{|c|c|c|c|}
\hline Yan Ürün & $\mathrm{ÇC}^{(1)}$ & $\mathrm{UK}^{(2)}$ & ÇC80UK20(3) \\
\hline$k^{(4)} \quad(\mathrm{m} / \mathrm{s})$ & $\sim 7.76 \times 10^{-8}$ & $10^{-9}<\mathrm{k}<10^{-8}$ & $\sim 2.17 \times 10^{-8}$ \\
\hline
\end{tabular}

Notlar:

(1) Çelik cürufu (2) Uçucu kül ${ }^{(3)} \% 80$ çelik cürufu - \%20 uçucu kül karışımı ${ }^{(4)}$ Hidrolik iletkenlik katsayıs1 ${ }^{(5)}$ Permeabilite deneyleri ASTM D5856-15e uygun olarak \%100 Proktor sıkılığında hazırlanmış örnekler üzerinde düşen seviyeli permeabilite yöntemi uygulanarak çok tekrarlı ölçümler alınarak tamamlanmıştır. ${ }^{(6)}$ Uçucu kül için elde edilen ölçümlerin hassasiyeti düşük olduğu için hidrolik iletkenlik aralık olarak verilmiştir.

Bu çalışmada kullanılan çelik cürufu için elde edilen hidrolik iletkenlik katsayısı, temiz kum ve kum-çakıl karışımlarına göre daha düşük, daha çok ince kumlar ve silt-kum karışımlarına yakındır. Bunun sebebi, çelik cürufunun $\mathrm{D}_{50}$ değeri 0.85 olsa da, ağırlıkça \%30'a yakın kısmının ince kum ve siltten oluşması ve bu ince malzemenin geçirimlilik davranışında 
baskın olmasıdır. Bununla beraber, numuneler kompaksiyon sonrası doygunluğa ulaşırken çelik cürufunun kimyasal bileşiminde bulunan serbest kirecin daneler arasında az da olsa bir miktar çimentolaşmaya (bağlayıcılığa) sebep olması da bu sonucu doğurmuş olabilir. \%80 çelik cürufu-\%20 uçucu kül karışımında silt boyutu arttığı için karışım için elde edilen hidrolik iletkenlik değeri, beklendiği gibi çelik cürufuna kıyasla daha düşüktür.

\subsection{Kayma Dayanımı}

Sırasıyla yaklaşık olarak \%17 ve \%14 su muhtevasında ve $\gamma_{d \text {, max }}$ değerlerinde hazırlanan çelik cürufu ve uçucu kül örnekleri $50 \mathrm{kPa}, 100 \mathrm{kPa}, 150 \mathrm{kPa}$ ve $300 \mathrm{kPa}$ normal gerilmeleri altında kesme kutusunda kesilmiştir. Çelik cürufu ve uçucu küle ait yatay yer değiştirme - kayma gerilmesi grafikleri Şekil 7a ve Şekil 7b'de görülmektedir. Genel olarak çelik cürufu örneklerine ait yatay yer değiştirme - kayma gerilmesi eğrileri yarı- belirgin bir pik değere ulaştıktan sonra biraz düşerek yaklaşık düz bir plato yapmıştır. Uçucu kül örneklerinde ise belirgin bir pik davranışı gözlenmemiştir.

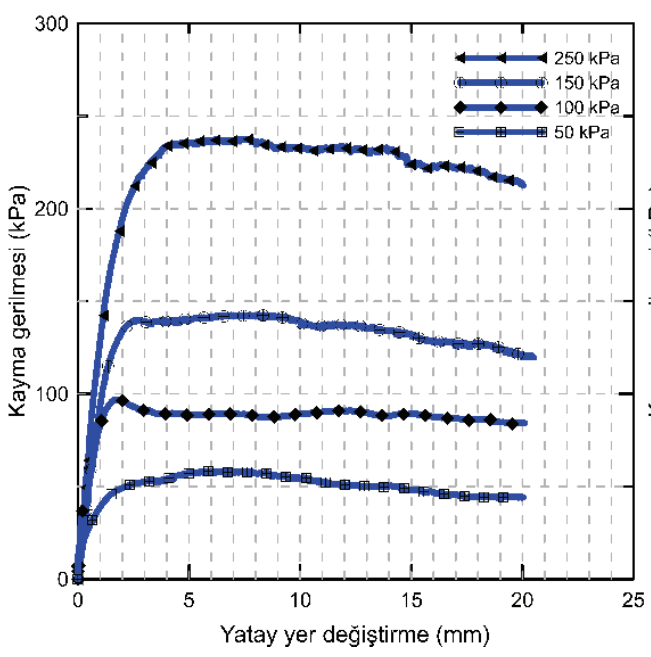

(a)

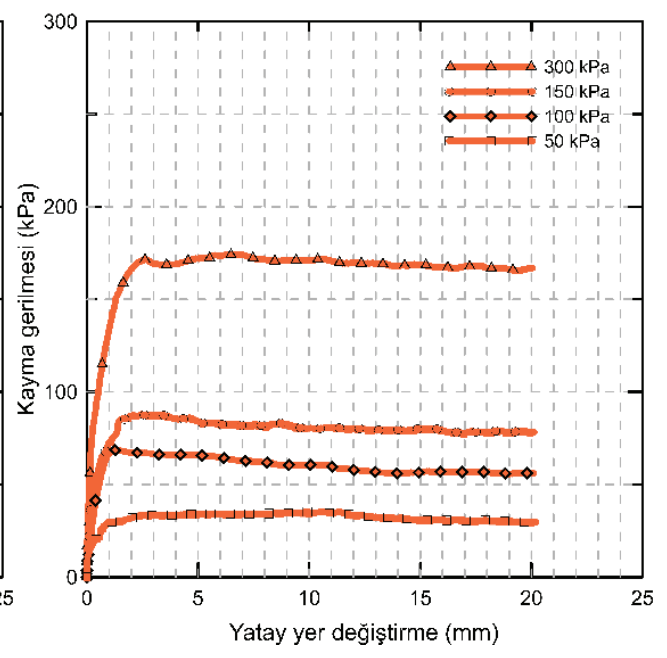

(b)

Şekil 7 - Yatay yer değiştirme - kayma gerilmesi:(a) ÇC, (b) UK

Çelik cürufu için elde edilen pik kayma dayanımları ve bu değerlere karşılık gelen pik kayma dayanımı parametreleri: Mohr-Coulomb pik sürtünme açısı - kohezyon $\left(\phi_{p}-c\right)$ Şekil 8a'da görülmektedir. Bu çalışmada kalıcı (kritik-durum) içsel sürtünme açılarının belirlenmesi hedeflense de direk kesme kutusundan elde edilen sonuçlar, ulaşılan deplasmanların bu kalıcı duruma erişmek için yeterli olmayabileceğine işaret etmektedir. Bu sebeple test sonundaki deplasmanlarda (plato kısmında) kayma dayanımı değerleri "deney-sonu sürtünme açısı" olarak sunulmaktadır. Bu deney sonu sürtünme açılarının kalıcı (kritik-durum) sürtünme açılarından bir miktar yüksek ve yakın olacağı öngörülmektedir. Çelik cürufu için her normal gerilme değerine karşılık gelen deney sonu kayma dayanımları ve hesaplanan içsel sürtünme açısı Şekil 8b'de görülmektedir. 
Çelik cürufu örnekleri, \% 100 Proktor sıkılığında hazırlandıkları ve dane şekilleri (açılı) kesme sırasında kenetlenmeye uygun olduğu için yer değiştirme kesme grafiklerinde pik gözlenmesi beklenen bir sonuçtur. Az belirgin bir pik gözlenmesinin temel sebebi malzemenin görece daha fazla ince kum ve silt içermesi ve kenetlenmede büyük rol oynayan çakıl boyutunda danelerin eksikliği olabilir [30]. Buna rağmen, bu görece ince dane çap1 dağılımındaki çelik cürufunun pik kayma dayanımı değerleri dahi, benzer dane çapı dağılımına sahip silika kumlarında gözlenen değerlerden daha yüksektir. Çelik cürufu için deney-sonu sürtünme açısı ise yaklaşık $40.2^{\circ}$ olarak belirlenmiştir, bu değer de çok köşeli kırma kumlarda ve daha çok çakıl içeren doğal granüler malzemelerde görülen değerler kadar yüksektir. Çelik cürufunun demir ve magnezyum içeren mineralojik yapısı ve pürüzlü yüzeyleri yüksek bir deney-sonu içsel sürtünme açısına sebep olmaktadır. Bu sonuçlar Türkiye'de üretilen BOF tipi çelik cürufunun, görece ince ve az çakıl içeren dane çap1 dağılımlarının bile kayma dayanımı açısından avantajlı bir dolgu malzemesi olduğunu göstermektedir.

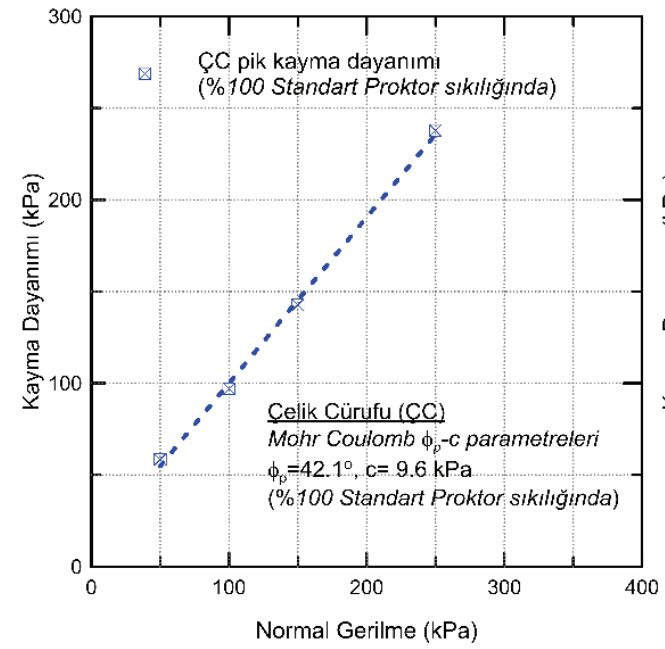

(a)

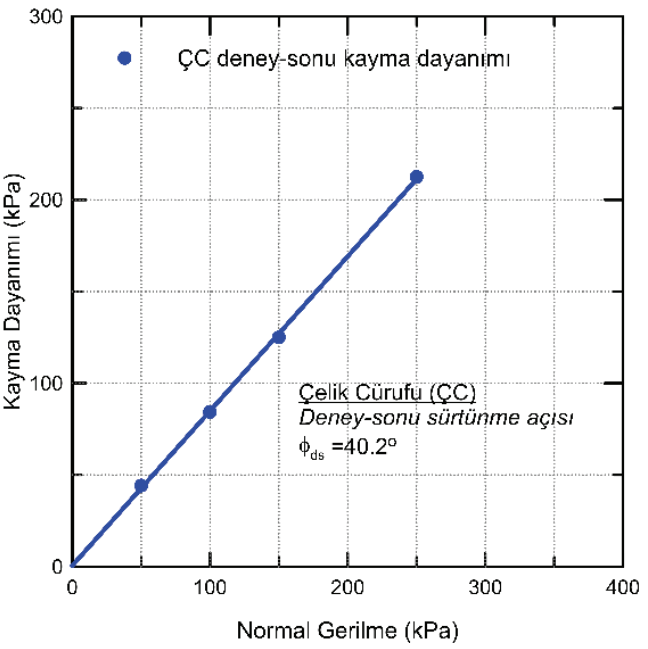

(b)

Şekil 8 - ÇC için elde edilen kayma dayanımı parametreleri: (a) Mohr-Coulomb $\phi_{p}-c$ parametreleri, (b) Deney-sonu sürtünme açısı

Uçucu kül örnekleri için elde edilen pik kayma dayanımları ve Mohr-Coulomb pik sürtünme açısı - kohezyon $\left(\phi_{p}-c\right)$ fit parametreleri Şekil 9a'da, deney-sonu kayma dayanımları ve sürtünme açısı da Şekil 9b'de görülmektedir. Uçucu kül örnekleri için deney sonu sürtünme açısı yaklaşık $28.9^{\circ}, \phi_{p}-c$ fit parametreleri de $29^{\circ}-8 \mathrm{kPa}$ olarak belirlenmiştir. Uçucu kül örnekleri için elde edilen yatay-deplasman ve kayma gerilmesi eğrileri incelendiğinde pik ve plato değerlerinin birbirine yakın olduğu gözlenmiştir(bkz. Şekil 9b). Uçucu kül örneklerinde kesme sırasında pikin daha az belirgin görülmesi malzemenin çoğunlukla silt boyutunda olmasıyla ve dane şekillerinin yuvarlak olmasıyla ilişkilendirilebilir. Bu iki özellik dane kenetlenmesine karşı çalışarak, uçucu külün pik kayma dayanımı açısının kalıcı içsel sürtünme açısına yakın çıkmasına sebep olmaktadır. 


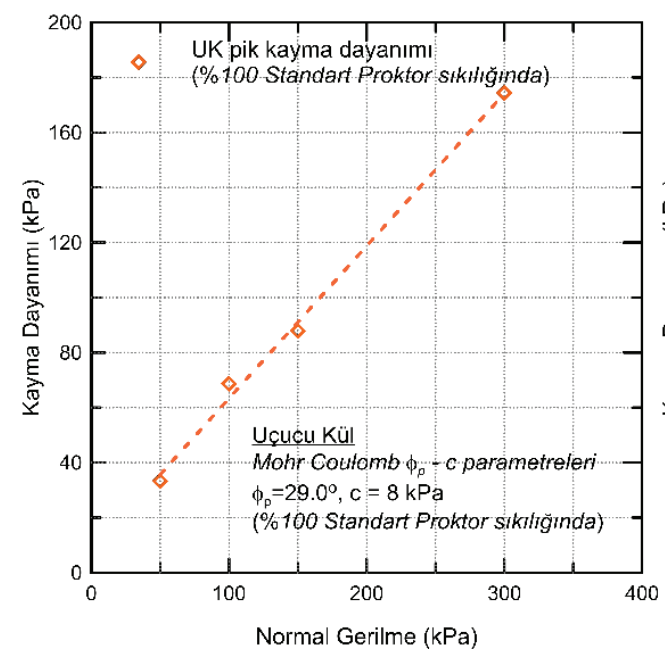

(a)

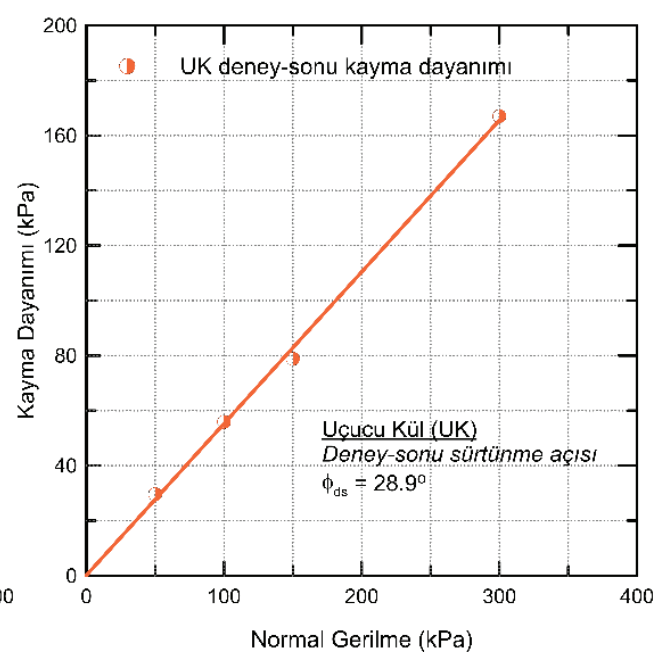

(b)

Şekil 9 - UK için elde edilen kayma dayanımı parametreleri: (a) Mohr-Coulomb $\phi_{p}-c$ parametreleri, (b) Deney-sonu sürtünme açısı

Bachus ve diğg. (2019) dünyanın değişik yerlerinden elde edilen uçucu küller üzerinde yapılan 90'ın üzerinde pik ya da kalıcı (kritik-durum) olduğunun çoğunlukla belirtilmediği deney sonucunu derleyerek uçucu küllerin içsel sürtünme açısı için $26^{\circ}-43^{\circ}$ aralığını belirlemiştir [65].

Buna ek olarak, Bachus ve diğ. (2019) üç eksenli deneylerden elde ettikleri sonuçlara dayanarak, sekiz (8) farklı uçucu kül için kalıcı (kritik-durum) içsel sürtünme açılarını $29^{\circ}{ }_{-}$ $36^{\circ}$ aralığında elde etmiştir. Bu çalışmada da elde edilen deney sonu içsel sürtünme açısı sunulan bu aralıkla uyumludur [65]. Pik içsel sürtünme açısı ise deney sonu için elde edilen değere oldukça çok yakındır. Sadece $\phi_{p}$ kullanılırsa; yani c $=0$ için, $\phi_{p}$ değeri $30.6^{\circ}$ 'ya karşılık gelmektedir, bu değer de literatürdeki pik değerler için yayımlanan aralıktadır.

$\% 80$ çelik - cürufu-\%20 uçucu kül karışımı ise belirlenen $w_{\text {opt }}(\% 14)$ ve $\gamma_{\mathrm{d} \text {,max }}$ değerlerine karşılık gelen \%100 Standart Proktor sıkılığında hazırlanmış ve $50 \mathrm{kPa}, 100 \mathrm{kPa}, 150 \mathrm{kPa}$, $200 \mathrm{kPa}$ ve $300 \mathrm{kPa}$ normal gerilmeleri altında kesme kutusu deneyleri yapılmıştır. \%80 çelik cürufu - \%20 uçucu kül karışımına ait yatay yer değiştirme - kayma gerilmesi ve yatay yer değiştirme - düşey yer değiştirme eğrileri sırasıyla Şekil 10a ve 10b'de görülmektedir. \%80 çelik cürufu-\%20 uçucu kül karışımı için elde edilen pik kayma dayanımları ve MohrCoulomb pik sürtünme açısı - kohezyon $\left(\phi_{p}-c\right)$ parametreleri Şekil 11a'da, deney-sonu kayma dayanımları ve bu dayanımlara karşılık gelen sürtünme açısı değeri de Şekil 11b'de görülmektedir. Çelik cürufu, uçucu kül ve $\% 80$ çelik cürufu - \%20 uçucu kül karışımı için kirik-durum zemin mekaniği ilkeleri çerçevesinde elde edile kayma dayanımı değerleri Tablo 7'de özetlenmektedir. 


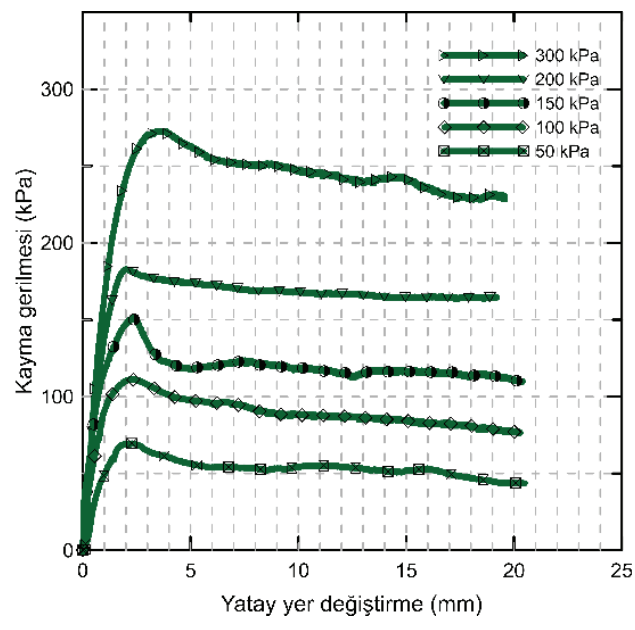

(a)

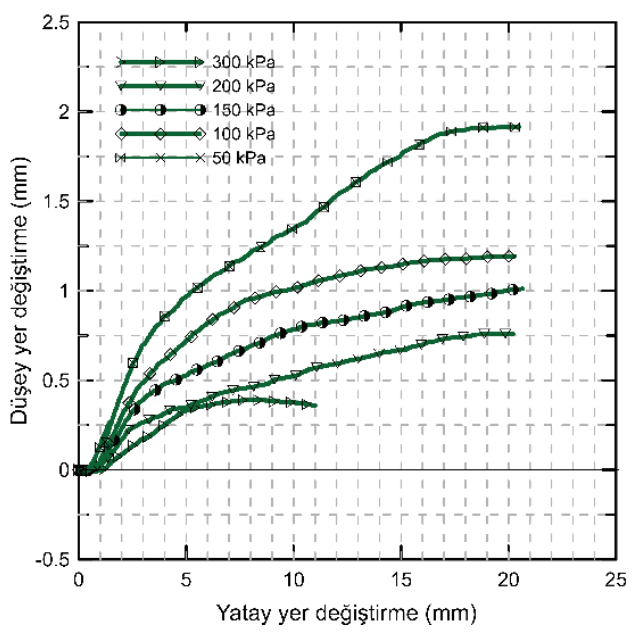

(b)

Şekil 10 - ÇC80UK20 Karışımı: (a) Yatay yer değiştirme- kayma gerilmesi, (b) Yatay yer değiştirme- düşey yer değiştirme

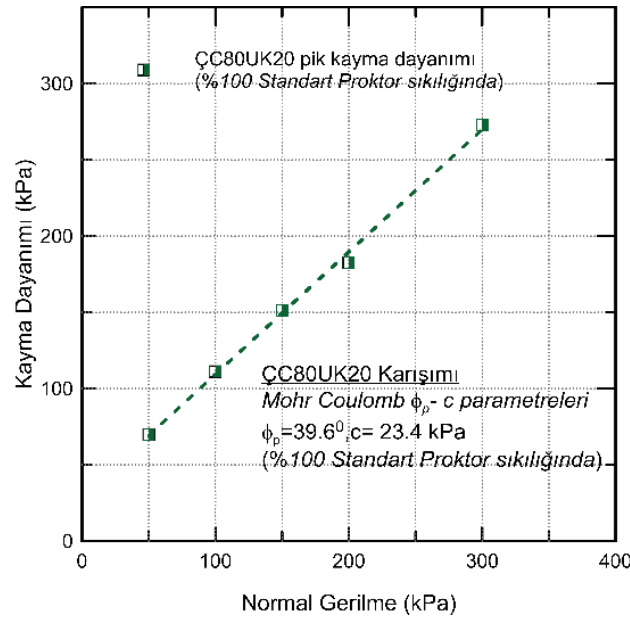

(a)

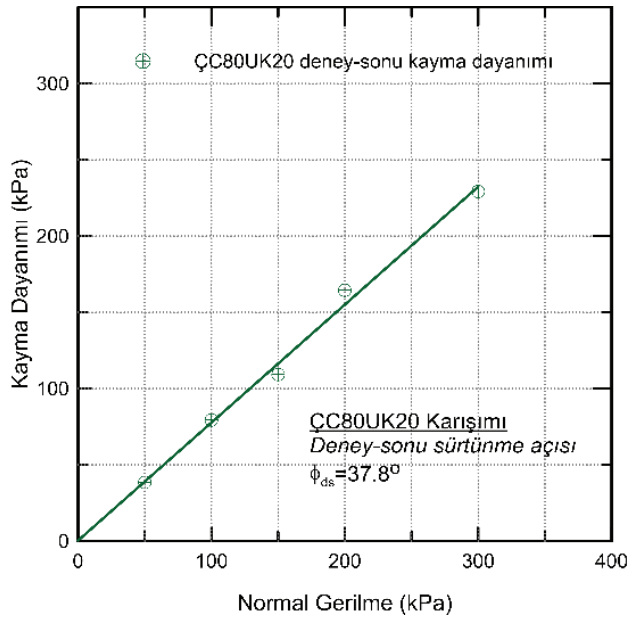

(b)

Şekil 11 - ÇC80UK20 için elde edilen kayma dayanımı parametreleri: (a) Mohr-Coulomb $\phi_{p}$ - c parametreleri, (b) Deney-sonu sürtünme açısı

Çelik cürufu danelerinin ağırlıkça \%20 oranında uçucu kül ile yer değiştirmesiyle elde edilen ÇC80UK20 örneğinin deney-sonu sürtünme açısı yaklaşık $37.8^{\circ}, \phi_{p}-c$ fit parametreleri de $39.6^{\circ}-23.4 \mathrm{kPa}$ olarak belirlenmiştir. Uçucu külün etkisiyle karışımın deney-sonu kayma dayanımı çelik cürufundan yaklaşık \% 10 daha düşük elde edilmiştir ve buna karşılık gelen 
deney-sonu içsel sürtünme açısı ise çelik cürufu için elde edilenden yaklaşık $2.5^{\circ}$ daha düşüktür. Karışımın pik kayma dayanımı değerleri ise çelik cürufu için elde edilenlere oldukça yakındır ve hatta bazı normal gerilmeler için karışım için elde edilen değerler çelik cürufu için elde edilenden daha yüksektir. Pik kayma dayanımı değerlerinde deney-sonu değerlerinde görüldüğü gibi bir düşüş görülmemesi karışımın dane çapı dağılımı ile ilişsilendirilebilir. Uçucu kül etkisiyle karışımın daha geniş bir dane çapı dağılımına sahip olması ve boşlukların dolması dilatasyonun artmasına ve pik dayanımların çelik cürufu ile hemen aynı kalmasına sebep olmuştur. Çelik cürufu ve $\% 80$ çelik cürufu - $\% 20$ uçucu kül örneklerine ait dayanım parametreleri doğal çakıllı kumlarla kıyaslanır seviyededir.

Tablo 7'deki değerler incelendiğinde, uçucu kül örneklerinin pik ve deney-sonu kayma dayanımı parametrelerinin çelik cürufu ve $\% 80$ çelik cürufu - \%20 uçucu kül karışımına göre çok daha düşük olduğu görülmektedir. Ancak, çelik cürufunda ağırlıkça \% 20 oranında uçucu külle yer değiştirme yapılması, çelik cürufunun pik dayanım değerlerinde bir düşüşe sebep olmazken, kalıcı kayma dayanımı parametrelerinde yaklaşık \%10'luk bir düşüşe sebep olmuştur. Bu sonuçlar uzun süreli şişme problemini hafifletmek için üretilen $\% 80$ çelik cürufu - \%20 uçucu kül karışımının kayma dayanım açısından çelik cürufuna yakın bir performans göstereceğine işaret etmektedir.

Tablo 7 - Yan ürünlerin ve karışımın kayma dayanımı değerleri

\begin{tabular}{ccc}
\hline Yan Ürün & Deney-sonu sürtünme açıs1 & $\begin{array}{c}\text { (2) } \\
\text { Pik-durum Mohr-Coulomb } \\
\phi-c \text { Parametreleri }\end{array}$ \\
\hline \hline ÇC $^{(1)}$ & $40.2^{\circ}$ & $42.1^{\circ}-9.6 \mathrm{kPa}$ \\
UK $^{(2)}$ & $28.9^{\circ}$ & $29.0^{\circ}-8 \mathrm{kPa}$ \\
ÇC80UK20 $^{(3)}$ & $37.8^{\circ}$ & $39.6^{\circ}-23.4 \mathrm{kPa}$ \\
\hline
\end{tabular}

\section{Notlar:}

(1) Çelik cürufu (2) Uçucu kül (3) \%80 çelik cürufu - \%20 uçucu kül karışımı

(4) Tüm örnekler Standart Proktor deneylerinden elde edilen maksimum kuru birim hacim ağırlık ve optimum su muhtevasında hazırlanmıştır.

\section{5. Çevresel Riskler}

Uçucu kül ve çelik cürufunun faydalı kullanımıyla ilgili olarak ortaya çıkabilecek çevresel risklerin belirlenebilmesi için bir seri deney yapılmıştır. Bu deneylerin temel amacı korozyon ve ağır metal salımı riskinin olup olmadığının belirlenebilmesidir. Kısa-süreli ve uzun-süreli çevresel etkiler ancak belirlenen risklere yönelik saha ve laboratuvar çalışmaları ve kirletici taşıma modellemeleri yapılarak belirlenebilir. Bu çalışmadaki ölçümler ve analizler, bundan sonra bu konuda yapılacak çalışmalar için bir indikatör olma niteliğindedir.

pH ve elektrik iletkenliği ölçümleri, malzemelerin potansiyel korozif özelliklerine işaret eder. Asidik ve yüksek bazik ortamların bazı metallerin korozyon hızını arttırdığı bilinirken, elektrik iletkenliği yüksek olan ortamların da korozyonu kolaylaştırdığı bilinmektedir. \%100 Proktor sıkılığında hazırlanan çelik cürufu, uçucu kül ve $\% 80$ çelik cürufu - $\% 20$ uçucu kül 
karışımında ölçülen elektrik iletkenliği ve pH değerleri, eluatta ölçülen pH değerleriyle beraber Tablo 8'de özetlenmektedir.

Elektrik rezistansı 10 ohm-m'un altında olan zeminlerin elektrik iletkenliği ve buna bağlı olarak da korozyon potansiyelleri çok yüksek olarak değerlendirilir. $\mathrm{pH}$ değerleri 4 'ten küçük veya 11.5 'tan yüksek solüsyonlar genellikle korozif özellikler taşır. Su varlığı iletkenliği arttırdığı için, kuru zeminlerde korozyon hızı doygun duruma göre daha düşüktür [66]. Tablo 8 'deki değerler incelendiğinde, sıkıştırılmış çelik cürufu ve uçucu kül örnekleri için ölçülen rezistans 10 ohm-m'nin altındadır. \%80 çelik cürufu - \%20 uçucu kül karışımı için ölçülen değer ise yaklaşık 10 ohm-m'dir. Tüm doygun örneklerde, kuru örneklere göre rezistans değerlerinde beklenen düşme gözlenmiştir.

Sıkıştırılmış örneklerde ve hazırlanan eluatlarda $\mathrm{pH}$ ölçümlerinin sonuçları birbirleriyle uyumludur. Çelik cürufu içeren numuneler uçucu küle göre daha yüksek pH değerine sahiptir. Elektrik iletkenliği ve pH ölçümleri yan ürünlerin ve karışımın korozyon riski taşıdığına işaret etmektedir.

Tablo 8 - Elektrik iletkenliği ve pH ölçüm sonuçları

\begin{tabular}{|c|c|c|c|c|c|}
\hline \multicolumn{4}{|c|}{ Sıkıştırılmış Numunelerde } & \multicolumn{2}{|c|}{ Eluat } \\
\hline \multirow[b]{2}{*}{ Yan Ürün } & \multicolumn{2}{|c|}{ Elektrik Rezistansı } & \multirow[b]{2}{*}{ Ölçüm Aralığg1 } & \multicolumn{2}{|l|}{ pH } \\
\hline & $\begin{array}{c}\text { wopt } \\
\text { ohm-m }\end{array}$ & $\begin{array}{l}\text { Doyurulmuş } \\
\text { ohm-m }\end{array}$ & & N1 & $\mathrm{N} 2$ \\
\hline ÇÇ & 9.66 & 6.30 & $12.72-12.85$ & 12.66 & 12.80 \\
\hline UK & 8.43 & 5.43 & $11.41-11.47$ & 11.53 & 11.43 \\
\hline ÇC80UK20 & 10.05 & 5.88 & $12.67-12.70$ & 12.45 & 12.70 \\
\hline
\end{tabular}

Endüstriyel yan ürünlerin dolgu malzemesi olarak değerlendirilmesinde dikkat edilmesi gereken bir başka konu da bu malzemelerin içinden geçen yağmur suyuna ağır metal salma riskidir. Bunun için TS EN 12547-4 [61] standardına uygun olarak hazırlanan çelik cürufu ve uçucu kül numunesi eluatının analizi sonucunda, çevresel sorun yaratabilecek ağır metal parametreleri için elde edilen değerler analiz yöntemleriyle beraber Tablo 9'da sunulmaktadır. Tablo 9'da Çevre Bakanlığı'nın yayımladığı Atıkların Düzenli Depolanmasına Dair Yönetmeliği'ne göre III. Sınıf depolama tesisleri için kullanılan sınır değerler de sunulmaktadır [67] .

İçme suyu için sınır (limit) metal değerleri farklı ulusal ve uluslararası kaynaklara göre değişmektedir. Çevre Bakanlığı'nın Atıkların Düzenli Depolanmasına Dair Yönetmeliği'ne göre III. Sınıf depolama tesisleri için belirlenen sınır değerleri, ulusal ve uluslararası kaynaklara göre belirlenen içme suyu limitleri ile uyumlu ve hatta daha zorlayıcıdır. $\mathrm{Bu}$ yüzden Tablo 9'da kıyaslama amacıyla bu limit değerler de sunulmaktadır [67,68]. Tablo 9'daki analiz sonuçlarına göre, kullanılan çelik cürufu eluatındaki ağır metal salımları, bu 
limitin biraz üzerinde olan krom $(\mathrm{Cr})$ dışındaki tüm parametreler için bu limitlerin altındadır. Uçucu kül eluatı için durum farklıdır, uçucu kül eluatındaki ağır metal salımları, krom $(\mathrm{Cr})$, molbiden (Mo), antimon ( $\mathrm{Sb}$ ), ve selenyum $(\mathrm{Se})$ için bu limitlerin üzerindedir. Bu sonuçlar kullanılan uçucu külün çelik cürufuna göre çevresel açıdan daha büyük bir risk taşıdığına ve uçucu kül seçiminin önemine işaret etmektedir.

Bu çalışmada önerilen karışım ağırlıkça \%20 oranında uçucu kül içerdiği ve karışımda bir miktar çimentolaşma özelliği de gözlendiği için, karışımın metal salımlarının sade uçucu külün metal salımından çok daha az olması beklenmektedir. Buna rağmen tüm sonuçlar, \%80 çelik cürufu - \%20 uçucu kül karışımının da çevresel bir risk faktörü oluşturabileceğini göstermektedir.

$\mathrm{Bu}$ çalışmada yapılan basit analizler sadece oluşabilecek çevresel risklerin belirlenmesini hedeflemiştir. Ağır metal salımı ve yeraltı suyuna etkisi; malzemenin kullanım şekli, sahanın içme suyu kaynaklarına uzaklığı, ulaşım yolundaki jeolojik birimler, pH ve sıcaklık gibi birçok faktörün etkisi ile değişen ve detaylı incelenmesi gereken bir konudur. Kısa-süreli ve uzun-süreli çevre etkilerinin laboratuvar çalışmalarıyla değerlendirilmesi tamamlanmadan, yan ürünlerin sahada kullanılması uygun değildir.

Tablo 9 - Eluat (sızıntı suyu) analiz sonuçları

\begin{tabular}{|c|c|c|c|c|}
\hline \multirow{2}{*}{ Parametreler } & $\mathrm{ÇC}^{(1)}$ & $\mathrm{UK}^{(2)}$ & \multirow{2}{*}{$\begin{array}{l}\text { III.SD Limit }{ }^{(3)} \\
(\mathrm{mg} / \mathrm{L})\end{array}$} & \multirow{2}{*}{ Analiz Yöntemleri } \\
\hline & $(\mathrm{mg} / \mathrm{L})$ & $(\mathrm{mg} / \mathrm{L})$ & & \\
\hline Arsenik (As) & $<0.0005$ & 0.0154 & 0.05 & \multirow{5}{*}{ EPA 6020 B (ICP-MS) [62] } \\
\hline Baryum $(\mathrm{Ba})$ & 0.185 & 1.1792 & 2 & \\
\hline $\operatorname{Kadmiyum}(\mathrm{Cd})$ & 0.00005 & 0.00191 & 0.004 & \\
\hline Krom $(\mathrm{Cr})$ & 0.06092 & 0.5466 & 0.05 & \\
\hline Bakır(Cu) & 0.00586 & 0.007 & \multirow{3}{*}{$\begin{array}{c}0.2 \\
0.001 \\
0.05\end{array}$} & \\
\hline $\mathrm{C} 1 v a(\mathrm{Hg})$ & $<0.000025$ & $<0.000025$ & & TS EN ISO 17852 \\
\hline Molbiden (Mo) & 0.007 & 0.6656 & & \multirow{6}{*}{ EPA 6020 B (ICP-MS) [62] } \\
\hline Nikel (Ni) & 0.00173 & 0.00059 & 0.04 & \\
\hline Kurşun $(\mathrm{Pb})$ & 0.00092 & 0.00197 & 0.05 & \\
\hline Antimon (Sb) & $<0.0002$ & 0.0178 & 0.006 & \\
\hline Selenyum (Se) & 0.00557 & 1.0337 & 0.01 & \\
\hline Çinko(Zn) & 0.01634 & 0.0199 & \multirow{2}{*}{$\begin{array}{c}0.4 \\
-\end{array}$} & \\
\hline Katı madde $(\%)$ & $>99$ & $>99$ & & TS 9546 EN12880 [64] \\
\hline
\end{tabular}

\section{SONUÇLAR}

Dünya'da ve ülkemizde, hızla önem kazanmakta olan sıfır atık hedefinin gerçekleşmesi ancak yerel yan ürünlerin doğru karakterizasyonu ile mümkün olabilir. Malzemelerin 
mühendislik özelliklerinin belirlenmesinin yanı sıra, kullanım sırasında oluşabilecek çevre risklerinin belirlenmesi, kısa-süreli ve uzun-süreli çevre etkilerinin değerlendirilmesi ve bu etkileri azaltacak stratejiler üretilmesi önem taşımaktadır. Geri dönüşüm ve efektif kullanım oranlarının artmasını sağlayabilmek için bazen birden fazla malzemeyi birlikte kullanarak uygun mühendislik özelliklerine sahip karışımlar elde etmek uygun bir yöntem olabilir.

Diğer ülkelerde olduğu gibi Türkiye'de de çelik cürufunun özellikle kum ve silt boyutundaki ince daneli kısmı, su varlığında gösterdiği hacimsel dengesizlik nedeniyle faydalı kullanılamamaktadır. Bu çalışmada ülkemizde yüksek üretim miktarlarına sahip olan BOF tipi çelik cürufu kullanılarak ağırlıkça \%80 çelik cürufu ve \%20 uçucu kül (ÇC80UK20) içeren bir karışım üretilmiştir. Bu karışımın dolgu özellikleri, çelik cürufunun (ÇC) ve uçucu külün (UK) özellikleri ile beraber kıyaslamalı olarak laboratuvar çalışması sonuçlarına dayanarak sunulmaktadır. Bu çalışmadan elde edilen temel bulgular ve değerlendirmeler aşağıda özetlenmektedir.

Bu çalışmada kullanılan BOF tipi çelik cürufu (CÇ) ve F sınıfı uçucu kül (UK) USCS'e göre sırasıyla SP-SM ve ML olarak sınıflandırılabilir. \%80 çelik cürufu - \%20 uçucu kül içeren karışım (ÇC80UK20) ise USCS'e göre SM, AASHTO’ya göre A-1b olarak sınıflandırılabilir.

Uzun süreli serbest şişme deneyi sonuçlarına göre altı (6) ayın sonunda ÇC örneği için ölçülen hacimsel deformasyon yaklaşık \% 3.6'dır ve şişme davranışında bir sönümlenme yoktur. ÇC80UK20 örneği için ise altı (6) ayın sonunda ölçülen hacimsel deformasyon yaklaşık \%0.74'tür ve hacimsel genleşmenin büyük ölçüde sönümlendiği gözlenmiştir. Bu sonuç uçucu külle yer değiştirme yöntemiyle üretilen karışımın şişme açısından çelik cürufuna kıyasla beklenilen iyileştirmeyi gösterdiğine işaret etmektedir.

Kompaksiyon eğrilerinden elde edilen değerler incelendiğinde, UK'nın hafif, ÇC'nin ise ağır bir dolgu malzemesi olduğu görülmektedir. Karışımın Standart Proktor kompaksiyon eğrisinden elde edilen $\gamma_{\mathrm{d} \text {,max }} 19.30 \mathrm{kN} / \mathrm{m}^{3}$, wopt ise yaklaşı \% 14 'tür. Karışıma ait hidrolik iletkenlik değeri Proktor sıkılığında hazırlanmış bir örnek için laboratuvar ortamında 2.17 x $10^{-8} \mathrm{~m} / \mathrm{sn}$ olarak belirlenmiştir. Bu değer orta-düşük drenaj kapasitesine işaret etmektedir. $\mathrm{Bu}$ sonuç karışımın serbest drenaj gerektiren dolgu uygulamalarında kullanılması durumunda ek drenaj önemleri alınması gerekliliğine işaret etmektedir.

Kesme kutusu deney sonuçlarına dayanarak, ÇC ve UK örnekleri için elde edilen deney-sonu sürtünme açısı $\left(\phi_{d s}\right)$ sırasıyla $40.2^{\circ}$ ve $28.9^{\circ}$ olarak belirlenmiştir. Karışım (ÇC80UK20) için deney-sonu kayma dayanımı çelik cürufu için elde edilen değerden $\% 10$ daha düşüktür ve deney-sonu sürtünme açısı 37.8 ${ }^{\circ}$ dir. \%100 Proktor sıkılığında hazırlanan ÇC80UK20 için Mohr-Coulomb $\phi_{p}-c$ parametreleri yaklaşı olarak 39.6 $-23.4 \mathrm{kPa}$ (ya da $c=0$ için $43.3^{\circ}$ ) olarak belirlenmiştir. Karışım için elde edilen pik dayanım değerleri çelik cürufu için elde edilenlere oldukça yakındır. Bu durum karışımın dane çapı dağılımındaki değişikliğin yol açtığı dilatasyon eğilimindeki artış ile ilişkilendirilebilir.

$\mathrm{Bu}$ çalışmada yapılan analizler seçilen malzemelerin kullanımı ile oluşabilecek çevresel risklerin belirlenmesini hedeflemiştir. Elektrik iletkenliği ve pH ölçümlerine göre, bu çalışmada kullanılan tüm yan ürünler doğal dolgu malzemeleri ile kıyaslandığında daha korozif özellik taşımaktadır. Karışım (ÇC80UK20) için pH değerleri 12.4-12.7 aralığındadır, elektrik rezistansı ise kuru ve doygun numuneler için sırasıyla 10.1 ve 5.9 ohm-m'dir. Sızıntı suyu analizlerinin sonucuna göre, çelik cürufu eluatındaki ağır metal salımları, krom (Cr) 
dışındaki tüm ağır metaller için genel geçerli içme suyu limitlerinin altındadır. Uçucu kül eluatındaki ağır metal salımları ise krom $(\mathrm{Cr})$, molbiden $(\mathrm{Mo})$, antimon $(\mathrm{Sb})$, ve selenyum (Se) için bu limitlerin üzerindedir. Bu sonuçlar, seçilen uçucu kül kullanımının metal salım açısından yaratacağı çevre riskinin çelik cürufuna göre daha yüksek olduğuna işaret etmektedir. Bu parametrelerin eluatta içme suyu sınır değerleri üzerinde olması, sahada bu etkinin yeraltı suyunda da aynı oranda görüleceği anlamına gelmez. Malzemenin kullanım şekli, yeraltı suyu kaynaklarına uzaklığı, ulaşım yolundaki etkiler, $\mathrm{pH}$ ve sıcaklık gibi birçok parametre ağır metal salımını önemli ölçüde etkiler. Bu yüzden tüm bu etkiler araştırıldıktan sonra malzemelerin ve karışımın çevresel etkiler açısından da kullanılabilir ya da kullanılamaz olduğu değerlendirilmelidir.

Kısa-süreli ve uzun-süreli çevre etkilerinin laboratuvar çalışmalarıyla değerlendirilmesi tamamlanmadan, yan ürünlerin sahada kullanılması uygun değildir. Elde edilen sonuçlar karışımın çevresel etkilerinin daha detaylı incelenmesi gerektiğine işaret etmektedir. Ağır metal salımı açısından daha güvenli bir uçucu kül kullanılarak ve eluat hazırlı̆̆ yerine hidrolik iletkenlik deneyi sırasında elde edilen sızma suyu örnekleri kullanılarak sonuçların nasıl değiştiği gelecekte araştırılmalıdır. Seçilen karışımın, sadece ekonomik fizibilitesi değerlendirilirse, karıştırma masrafı ve karışımın ağırlı̆̆ da göz önünde bulundurulmalıdır. $\mathrm{Bu}$ açıdan karışımın ancak yan ürün kaynaklarına yakın bir uygulama sahasında kullanılması ekonomik olabilir.

\section{Semboller}

$\begin{array}{ll}\mathrm{G}_{\mathrm{s}} & : \text { Özgül ağırlık } \\ w & : \text { Su muhtevası } \\ w_{\text {opt }} & : \text { Likit limit su muhtevası } \\ \gamma_{\mathrm{d}} & : \text { Kuru birim hacim ağırlık }\left(\mathrm{kN} / \mathrm{m}^{3}\right) \\ \gamma_{\mathrm{d}, \mathrm{max}} & : \text { Maksimum kuru birim hacim ağırlık }\left(\mathrm{kN} / \mathrm{m}^{3}\right) \\ \phi_{p} & : \text { Mohr-Coulomb pik içsel sürtünme açısı }\left(^{\circ}\right) \\ c & : \text { Mohr-Coulomb kohezyonu }(\mathrm{kPa}) \\ \phi_{d s} & : \text { Deney-sonu içsel sürtünme açısı }\left(^{\circ}\right)\end{array}$

\section{Teşekkür}

Bu çalışma Tübitak 2232 117C018 No'lu proje kapsamında Türkiye Bilimsel ve Teknolojik Araştırma Kurumu (TÜBİTAK) tarafından desteklenmiştir. Yazar TÜBİTAK’a sağladığı maddi destek için teşekkürlerini sunar. Yazar ayrıca malzemeleri sağlayan çelik ve enerji üretim tesisi yetkililerine ve laboratuvar çalışmaları sırasında destek veren İnşaat Mühendisi İsmail Cantekin'e de teşekkürlerini sunar. 


\section{Kaynaklar}

[1] Association of State and Territorial Solid Waste Management Officials (ASTSWMO). 2006 Beneficial Use Survey. Survey Report, ASTSWMO -Beneficial Use Task Force, Washington, D.C., 2007.

[2] Segerstorm, W., Dove, J., Recycled materials in geo-construction: A Review of Potential Benefits and Hazards. Scientific Report, CPGR No 61, Virginia Tech Center for Geotechnical Practice and Research, Virginia Polytechnic Institute and State University, VA, 2010.

[3] Environmental Protection Agency (EPA). Methodology for Evaluating Beneficial Uses of Non-Hazardous Industrial Secondary Materials. Technical Report, No. 530R-16-011, Office of Resource Conservation and Recovery-Office of Land and Emergency Management, Washington, D.C., 2016.

[4] Ahmedzade, P., Sengoz, B., Evaluation of steel slag coarse aggregate in hot mix asphalt concrete. J. Hazard. Mater., 165,1-3, 300-305, 2009.

[5] Shen, D., Wu, C., Du, J., Laboratory investigation of basic oxygen furnace slag for substitution of aggregate in porous asphalt mixture. Constr Build Mater, 23,1, 453$461,2009$.

[6] Wu, S., Xue, Y., Ye, Q., Chen, Y., Utilization of steel slag aggregates for stone mastic asphalt (SMA) mixtures. Build Environ, 42, 7, 2580-2585, 2009.

[7] Ameri, M., Hesami, S., Goli, H., Laboratory evaluation of warm mix asphalt mixtures containing electric arc furnace (EAF) steel slag. Constr Build Mater, 49, 611-617, 2013.

[8] Montgomery, D.G., Wang, G., Instant-chilled steel slag aggregate in concretestrength related properties. Cem Concr Res, 21, 6, 1083-1091, 1991.

[9] Maslehuddin, M, Sharif, M.A., Shameem, M., Ibrahim, M., Barry, M.S., Comparison of properties of steel slag and crushed limestone aggregates. Constr Build Mater, 17, 2,105-112, 2003.

[10] Manso, J.M., Polanco, J.A., Losanez, M., Gonzales, J.J., Durability of concrete made with EAF slag as aggregate. Cem Concr Compos, 28,6, 528-534, 2006.

[11] Abu-Eishah, S.I., El. Dieb, A.S., Bedir, M.S., Performance of concrete mixtures made with electric arc furnace (EAF) steel slag aggregate produced in the Arabian Gulf region”. Constr Build Mater, 34, 249-256, 2012.

[12] Rondi, L., Bregoli, G., Sorlini, S., Cominoli, L., Collivignarelli, C., Plizzari, G., Concrete with EAF steel slag aggregate: A comprehensive technical and environmental characterization. Compos B Eng, 90, 195-202, 2016.

[13] Conjeaud, M., George, C. M., Sorrentino, F. P., A new steel slag for cement manufacture: mineralogy and hydraulicity. Cem Concr Res, 11, 1, 85-102, 1981.

[14] Tufekci, M., Demirbas, A., Genc, H., Evaluation of steel furnace slags as cement additives. Cem Concr Res, 27, 11, 1713-1717, 1997. 
[15] Altun, I.A., Yilmaz, I., Study on steel furnace slags with $\mathrm{MgO}$ additive in Portland cement. Cem Concr Res, 32, 8,1247-1249, 2002.

[16] Reddy, A.S., Pradhan, R.K., and Chandra, S., Utilization of basic oxygen furnace (BOF) slag in the production of a hydraulic cement binder. Int J Miner Process, 79, 2, 98-105, 2006.

[17] Serjun, V.Z., Mladenovic, A., Mirtic, B., Meden, A., Scancar, J., Milacic, R., Recycling of ladle slag in cement composites: Environmental impacts. Waste Manag, 43, 376-385, 2015.

[18] Vilaplana, A. S., Ferreira, V.J., Lopez-Sabrion, A.M., Aranda-Uson, A., LausinGonzalez, C., Berganza-Conde, C., Ferreira, G., Utilization of Ladle Furnace slag from a steelwork for laboratory scale production Portland Cement. Constr Build Mater, 94, 837-843, 2015.

[19] Tsakiridis., P.E., Papadimitriou, G.D., Tsivilis, S., Koroneos, C., Utilization of steel slag for Portland cement clinker production. J. Hazard. Mater., 152, 2, 805-811, 2008.

[20] Iacobescu, R.I., Koumpouri, D.,Pontikes, Y., Saban, R., Angelopoulos, G.N., Volarisation of electric arc furnace steel slag as a raw material for low energy belite cements". J. Hazard. Mater., 196, 287-294, 2011.

[21] Iacobescu, R.I., Angelopoulos, G.N., Jones, P.T., Blanpain, B., Pontikes, Y., Ladle metallurgy stainless steel slag as raw material in ordinary Portland Cement production: a possibility for industrial symbiosis. J Clean Prod, 112, 872-881, 2016.

[22] Poh, H.Y., Ghataora, S.G., Ghazireh, N., Soil stabilization using basic oxygen steel slag fines. J Mater Civil Eng, ASCE, 18, 2, 229-240, 2006.

[23] Ortega-Lopez, V., Manso, J.M., Cuesta, I.I., Gonzalez, J.J., The long-term accelerated expansion of various ladle-furnace basic slags and their soil-stabilization applications. Constr Build Mater, 68, 455-464, 2014.

[24] Yildirim, I.Z., Prezzi, M., Subgrade stabilisation mixtures with EAF steel slag: an experimental study followed by field implementation. Int J Pavement Eng, available online, DOI:10.1080/10298436.2020.1823389, 2020.

[25] Ghionna, V., Pedroni, S., Tenani, P., Veggi, S., Geotechnical investigation on steel slags mixtures for landfills embankments construction. Proceedings of the Second International Conference on Environmental Geotechnics, V2, 709-714, Osaka, Japan, November 5-8, 1996.

[26] Montenegro, J.M., Celemín-Matachana, M., Canizal, J., Setien, J., Ladle furnace slag in construction of embankments: expansive behavior. J Mater Civil Eng, ASCE, 25, 8, 972-979, 2013.

[27] Yildirim, I.Z., Prezzi, M., Experimental Evaluation of EAF Ladle Steel Slag as a GeoFill Material: Mineralogical, Physical \& Mechanical Properties. Constr Build Mater, 154C, 23-33, 2017.

[28] Juckes, L.M., The volume stability of modern steelmaking slags. Miner Process Extr M, 112, 3, 177-197, 2003. 
[29] Yildirim, I.Z., Prezzi, M., Steel Slag: Chemistry, Mineralogy, and Morphology. Proceedings of the International Foundations Congress \& Equipment Exposition (IFCEE), Geotechnical Special Publication No. 256, 2816-282, San Antonio, Texas, March 17-21, 2015.

[30] Yildirim, I.Z., Prezzi, M., Geotechnical Properties of Fresh and Aged Basic Oxygen Furnace Steel Slag. J Mater Civil Eng, ASCE, 27,12, 104015046, 1-9, 2015.

[31] Yayan, V. Current Situation in Turkish Steel Industry and Outlook. Turkish Steel Producers Associations' Presentation in $86^{\text {th }}$ OECD Steel Committee Meeting 25-26 March 2019, Paris, 2019. http://www.oecd.org (Erişim tarihi: 28.07.2020)

[32] World Steel Association (WSA), 2020 World Steel in Figures. WSA Annual Report, Belgium, 2020. www.worldsteel.org (Erişim tarihi: 28.07.2020)

[33] Türkiye Çelik Üreticileri Derneği (TÇÜD). Demir Çelik Cüruf Raporu, Çevre ve Şehircilik Bakanlığı, Ankara, 2015.

[34] Türkiye Çelik Üreticileri Derneği (TÇÜD), Basın Bülteni. TÇÜD, Ankara, 2020. http://celik.org.tr/en/turkiye-celik-ureticileri-dernegi-basin-bulteni-30/ (Erişim tarihi: 28.07.2020)

[35] Türkiye Çelik Üreticileri Derneği (TÇÜD), Türkiye Çelik Haritası. TÇÜD, Ankara, 2020. http://celik.org.tr/en/harita/ (Erişim tarihi: 28.07.2020)

[36] Öcal, Y. Demir Çelik Sektöründe Atık Yönetimi. Uzmanlık Tezi, Yayın No: 2911, İktisadi Sektörler ve Koordinasyon Genel Müdürlüğü, T.C. Kalkınma Bakanlığ1, 2014.

[37] T.C. Enerji ve Tabii Kaynaklar Bakanlığı.(ETKB), Bilgi Merkezi-Enerji, Elektrik, ETKB, 2020. http://www.oecd.org (Erişim tarihi: 28.07.2020)

[38] American Society of Testing Materials (ASTM), Standard Specification for Coal Fly Ash and Raw or Calcined Natural Pozzolan for Use in Concrete. ASTM C 618, West Conshohocken, PA, USA, 2019.

[39] Türker, P., Erdoğan, B., Katnaş, F., Yeğinobalı, A. Türkiye'deki uçucu küllerin sınıflandırılması ve özellikleri. TÇMB/ ARGE/Y03.03, Türkiye Çimento Müstahsilleri Birliği (TÇMB), Ankara, Türkiye, 2009.

[40] Atabey, İ.İ. F Sınıfı Uçucu Küllü Geopolimer Harcının Durabilite Özelliklerinin Araştırılması, Doktora Tezi, Erciyes Üniversitesi, 2017.

[41] Türkiye İstatistik Kurumu (TÜIK). Haber Bülteni. Termik Santral Su ve Atık İstatistikleri, Sayı:24873, 18 Aralık 2017. http://www.tuik.gov.tr (Erişim tarihi: 28.07.2020)

[42] Uyanık, S., Topeli, M., The opportunities and challanges of fly ash in Turkey. İskenderun Enerji Üretim ve Ticaret A.Ş. (ISKEN), 2014. http://www.ashtrans.eu/ (Erişim tarihi: 09.08.2020)

[43] Koh, T., Moon, S.-W., Jung, H., Jeong, Y., Pyo, S. A Feasibility Study on the Application of Basic Oxygen Furnace (BOF) Steel Slag for Railway Ballast Material. Sustainability, 10, 284, 2018. 
[44] Pathak, K.,Choudhary,R., Kumar, A., Damena, T.D. Feasibility assessment of the use of basic oxygen furnace slag in open graded asphalt courses. Int. J. Pavement Res. Technol, 12, 664-673, 2019.

[45] Dayığlu, A.Y., Geotechnical and environmental impacts of steel slag in embankments, Doktora tezi, University of Maryland, College Park, 2016.

[46] Dayioglu, A. Y., Aydilek, A. H., Cimen, O., \& Cimen, M. Trace Metal Leaching from Steel Slag Used in Structural Fills. J Geotech Geoenviron, ASCE, 144, 12, 04018089, 2018.

[47] Shen,W., Zhou, M., Ma, W., Hu, J., Cai, Z. Investigation on the application of steel slag-fly ash-phosphogypsum solidified material as road base material. Journal of Hazardous Materials, 164, 1, 99-104, 2009.

[48] Pasetto, M., Baldo, N. Re-use of industrial wastes in cement bound mixtures for road construction. Environ Eng Manag J, Environmental Engineering and Management Journal, 17, 2, 417-426, 2018.

[49] Falayi, T. A comparison between fly ash- and basic oxygen furnace slag-modified gold mine tailings geopolymers. Int J Energy Environ Eng 11, 207-217, 2020.

[50] Yildirim, I. Z., Prezzi, M., Vasudevan, M., Santoso, H. Use of soil-steel slag-class-C fly ash mixtures in subgrade applications. Publication FHWA/IN/JTRP-2013/06. Joint Transportation Research Program, Indiana Department of Transportation and Purdue University, West Lafayette, Indiana, 2013 (doi: 10.5703/1288284315188).

[51] Yildirim, I.Z. Türkiye'de Geo-malzemeler ve Sürdürülebilirlik: Çelik Cürufunun Hacim Değiştirme (Şişme) Davranışının Çeşitli Deneysel Metotlarla Belirlenmesi. Tübitak 2232 Proje No: 117C018, Sonuç Raporu,1-54, 2019.

[52] American Society of Testing Materials (ASTM), Standard test method for CBR (California Bearing Ratio) of laboratory compacted soils. ASTM D 1883-07, West Conshohocken, PA, 2018.

[53] American Society of Testing Materials (ASTM), Standard practice for reducing samples of aggregate to testing size. ASTM C 702/702M-18, West Conshohocken, PA, 2018.

[54] American Society of Testing Materials (ASTM), Standard test method for particlesize analysis of soils. ASTM D422-63, West Conshohocken, PA, 2007.

[55] American Society of Testing Materials (ASTM), Standard test methods for specific gravity of soil solids by water pycnometer. ASTM D854-10, West Conshohocken, PA, 2010.

[56] American Society of Testing Materials (ASTM), Standard test method for laboratory compaction characteristics of soil using standard effort [12,400 ft-lbf/ft3 $(600 \mathrm{kN}-$ m/m3)]. ASTM D698-00a, West Conshohocken, PA, 2010.

[57] American Society of Testing Materials (ASTM), Standard test method for measurement of hydraulic conductivity of porous material using a rigid-wall, compaction-mold permeameter. ASTM D5856-15, West Conshohocken, PA, 2015. 
[58] American Society of Testing Materials (ASTM), Standard test method for direct shear test of soils under consolidated drained conditions. ASTM D3080/D3080-11, West Conshohocken, PA, 2011.

[59] American Society of Testing Materials (ASTM), Standard test method for soil resistivity using the two-electrode soil box method. ASTM G187-18, West Conshohocken, PA, 2011.

[60] American Society of Testing Materials (ASTM), Standard test method for measuring $\mathrm{pH}$ of soil for use in corrosion testing. ASTM G51-95, West Conshohocken, PA, 2012.

[61] TS EN 12457-4. Atıkların nitelendirilmesi - Katıdan özütleme analizi- Granül katı atıkların ve çamurların katı özütlemesi için uygunluk deneyi - Bölüm 4 : Sıvı katı oranı 10 1/kg olan ve parçacık boyutu $10 \mathrm{~mm}$ 'den küçük (ölçüsü azaltılmış veya azaltılmamış) malzemeler için tek aşamalı parti deneyi. Türk Standartları Enstitüsü, Bakanlıklar-ANKARA, 2004.

[62] EPA SW846 Method 6020B. Inductively Coupled Plasma - Mass Spectrometry. Revision 2, U.S. Environmental Protection Agency, July 2014.

[63] TS EN ISO 17852. Su kalitesi - Civa tayini - Atomik floresans spektrometresi kullanan yöntem. Türk Standartları Enstitüsü, Bakanlıklar-ANKARA, 2009.

[64] TS 9546 EN 12880. Çamurların karakterizasyonu- Kuru kalıntı ve su muhtevası tayini. Türk Standartları Enstitüsü, Bakanlıklar-ANKARA, 2002.

[65] Bachus, R.C., Terzario, M., Pasten, C., Chong, S. H., Dai, S., Cha, M.S., Kim, S.J., Jang, Papadopoulos, E., Roshankhah, S., Lei, L., Garcia, A., Park, J., Sivaram, A., Santamarina, F., Ren, X., and Santamarina, J. C., Characterization and engineering properties of dry and ponded Class-F fly ash. J. Geotech. Geoenviron. Eng., ASCE, 145, 3, $04019003,1-11,2019$.

[66] Roberge, P. R. Corrosion Inspection and Monitoring. Wiley Series in Corrosion, R.Winston Revie, Royal Military College of Canada Ontario, Canada, WileyInterscience, A John Wiley \& Sons, Inc., 2007.

[67] RG:26.03.2010-27533. Atıkların Düzenli Depolanmasına Dair Yönetmelik, Çevre Bakanlığ1, 2010.

[68] Oğuz, T.C. İçme suyu arıtımında yaygın olarak karşılaşıan su kalite problemleri ve arıtımı için çözüm önerileri. Uzmanlık Tezi, TC Orman ve Su İşleri Bakanlığı, 2015. 
